\title{
Diversity and preservation of Pleistocene tetrapods from caves of southwestern Bahia, Brazil
}

\author{
Rafael Costa da Silva ${ }^{\mathrm{a}, *}$, Mylène Berbert-Born ${ }^{\mathrm{b}}$, Dandara Evangelista Ferreira Bustamante ${ }^{\mathrm{c}}$, \\ Taís Novaes Santoro ${ }^{\mathrm{c}}$, Fernando Sedor ${ }^{\mathrm{d}}$, Leonardo dos Santos Avilla ${ }^{\mathrm{e}}$

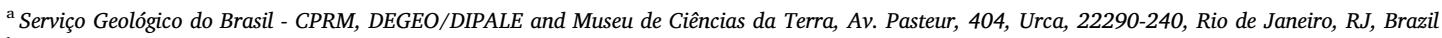 \\ ${ }^{\mathrm{b}}$ Serviço Geológico do Brasil - CPRM, SUPLAM, Setor Bancário Norte - SBN quadra 02 bloco H - Edifício Central Brasília, 5a andar, 70040-904, Brasília, DF, Brazil \\ ${ }^{\mathrm{c}}$ Serviço Geológico do Brasil - CPRM, DEGEO/DIPALE, Av. Pasteur, 404, Urca, 22290-240, Rio de Janeiro, RJ, Brazil \\ ${ }^{\mathrm{d}}$ Universidade Federal do Paraná, Museu de Ciências Naturais, Centro Politécnico, 81531-990, Curitiba, PR, Brazil \\ ${ }^{\mathrm{e}}$ Laboratório de Mastozoologia, Departamento de Zoologia, Universidade Federal do Estado do Rio de Janeiro (UNIRIO), Av. Pasteur 458, Prédio de Ciências Biológicas, \\ sala 501, Urca, 22240-290, Rio de Janeiro, RJ, Brazil
}

\section{A R T I C L E I N F O}

\section{Keywords:}

Mammals

Xenarthra

South America

Karst

Megafauna

Taphonomy

\begin{abstract}
A B S T R A C T
The study of two caves from the Serra do Ramalho region is here presented, this is one of the most important karstic areas in Brazil. A taxonomic analysis revealed 29 taxa including Xenarthra, Cetartiodactyla and Carnivora, ranging from Late Pleistocene to Early Holocene. Taphonomic studies reveal taphocoenosis consisting mainly of complete elements, without significant transportation, but also of transported elements, composing spatial-mixed, predominantly in situ-preserved assemblages. The predominance of Xenarthrans found within the caves is probably biased by a taphonomic pattern since these animals would have life habits related to cave environments, therefore with higher chances of preservation. There is evidence of accidental death of the scelidotheriines in Lapa dos Peixes cave, where entrapment of the animals during one or more events of river flooding is pointed as a hypothesis. Deposition took place within different periods of dry and humid climate incorporating bones in clastic and chemical deposits. Cycles of sedimentary deposition and reworking (erosion) may have acted in generating complex and overlapping depositional patterns with time averaging. During depositional phase, while the cave environment was occupied rather by Xenarthrans, parts of other animals were transported in the scope of fluvial systems and gravity loads, as well as by accidental falling or scavengers. The sedimentary deposits are currently being eroded by rain runoff in both caves, causing the reallocation of finer sediments to deeper conduits but the fossils keep close to their original location. This process is exposing a large amount of fossils, allowing extensive sampling which would be impossible with active excavations, since it would require an excessively longer time and damages to the caves.
\end{abstract}

\section{Introduction}

There is a great diversity of Pleistocene tetrapod fossils in Brazil, found in several types of sedimentary deposits including those from alluvial terraces, natural tanks and caves. The state of Bahia presents a significant fossil record due to its large territory and nature of deposits, especially in its central-northern region (e.g. Cartelle, 1999; Cartelle et al., 2008; Dantas et al., 2013a, b; Scherer et al., 2017; Vasconcelos et al., 2018). A great diversity of mammalian taxa were recorded in the Bahia state including the orders Pilosa, Carnivora, Proboscidea, Notoungulata, Perissodactyla, Artiodactyla and Litopterna (Cartelle, 1999).
Although in recent years there has been a substantial increase in studies on Brazilian Pleistocene fossils, many sites with great paleontological potential have not yet been prospected. Particularly, the southwestern region of Bahia state covers large systems of caves which have been poorly studied from the paleontological perspective. Occurrences of tetrapod fossils in caves are remarkable not only by their quantity and quality preservation but also by a unique depositional context related to the distinctiveness and imprisonment of karstic environments (Palmer, 1991, 2007; Neto and Ribeiro, 2016; Vasconcelos et al., 2018). However, due to logistic and technical challenges when collecting fossils in caves, most are isolated records or solely intended for studies on taxonomic determination or revision,

\footnotetext{
* Corresponding author.

E-mail addresses: rafael.costa@cprm.gov.br, paleoicno@yahoo.com.br (R.C.d. Silva), mylene.berbertborn@cprm.gov.br (M. Berbert-Born),

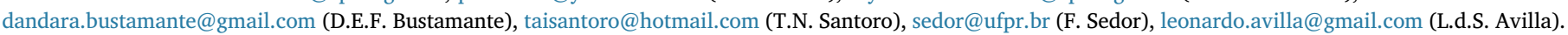


with few information about the representativity of fossil association and its relationship with the environment context of the cave.

The project "Geodiversidade da Depressão Sanfranciscana Geokarst 1" (Geodiversity of Sanfranciscana Depression), conducted by the Serviço Geológico do Brasil - CPRM (Geological Survey of Brazil), sought to recognize the organization, operation and vulnerability of karstic systems between the Urucuia Formation sandstone plateau and the riverbed of São Francisco river, in the hydrographic context of the Corrente river watershed and its surroundings (middle section of São Francisco river), southwestern Bahia state. This area has special hydrological and speleological relevance. To such purpose, speleological surveys were conducted in several dozens of caves located in different lithostratigraphic, geomorphological and hydrogeological contexts.

The Serra do Ramalho plateau covers a remarkable set of speleological, paleontological and archeological sites, an outstanding karstic compartment located in the interfluve of Cariranha, Corrente and Formoso rivers. Such region is characterized by several underground river systems which are very hydrologically dynamic and can reach tens of kilometers. The high-water energy of most of these systems associated to the geomorphological and hydrological settings in this region result in great sedimentary movement in both surface and subsurface. Therefore, these systems are naturally potential fossil reservoirs related to different facies of cave depositional systems.

In this scenario, many cave deposits are found in frank erosion by persistent or temporary river systems, with lower fossiliferous potential, while others are isolated from fluvial influence, suffering local and seasonal erosion by low energy rainfall runoffthen leading the outcropping of fossils. As fossils are exhumed and/or relocated they become susceptible to degradation. Several sites are found fairly exposed to rainwater, especially in caves lacking groundcover, usually located in the edges of karst plateau and the remaining mounds that surround the erosive fronts.

This contribution is a result of paleontological studies in caves under the aforementioned circumstances. The fossils were recovered from sedimentary deposits which are under erosion by seasonal pluvial activity causing rapid exposure, and as consequence they are subject to degradation. Thus, in addition to an extensive paleontological assessment, which allowed to record sedimentary dynamics and paleobiological features of an important part of the studied karstic system, the collection was also made intending to rescue materials.

In compliance with the Brazilian environmental legislation and because of uncertainty consequences of cave environment interventions, this study did not involve excavation in sedimentary deposits. It is based on the naturally exposed material washed-in by erosion. On the other hand, the extensive sampling of naturally exposed materials has allowed a considerable record of fossil occurrences as well as detailed characterization of taphonomic aspects, gathering relevant information on previous hydrologic and sedimentary dynamics of this karstic system, which supports some paleoenvironmental hypotheses suggested herein.

\section{Material and methods}

The fossils came from two caves located on the boundary of Serra do Ramalho plateau, southwestern Bahia (Fig. 1), where limestone outcrops as stepped extensive bare rocks (Fig. 2A): 1) Lapa dos Peixes I (Fish Cave I, $13^{\circ} 49^{\prime} 22,08^{\prime \prime}$ S; $43^{\circ} 57^{\prime} 25,20^{\prime \prime}$ W, Carinhanha municipality); and 2) Gruna das Três Cobras (Three Snakes Cave, $13^{\circ} 37^{\prime \prime} 7,58^{\prime \prime}$ S; $43^{\circ} 45^{\prime} 11,49^{\prime \prime}$ W, Serra do Ramalho municipality). Both caves are placed at the bottom of the plateau, in discharge zones of the karst aquifer. The Gruna das Três Cobras is more specifically located in a remnant karst hill, already detached from the erosive front of the plateau.

The collections were grouped in November of 2012, May and August of 2013 and January of 2014 by the authors R.C. Silva and M. Berbert-Born and the fieldtrips were supported by ICMBio/Cecav permits number 37198, 39332 and 40585 . The field works aimed to rescue and study the paleontological material which is naturally exposed by pluvial action within the caves. The location of all collected samples was plotted on the speleotopographic map of the respective cave, as illustrated in the discussion part. However, as the material was mainly remobilized, azimuthal/stratigraphic orientation data were not considered relevant. The collection points were photographed before and after fossil removal in order to record modifications in the cave environment, according to the collection permit requirements.

A total of 398 Pleistocene tetrapod specimens were recovered from the two caves studied here: 1) at Lapa dos Peixes, 117 samples were collected; and 2) Gruna das Três Cobras revealed a total of 281 samples.

At Lapa dos Peixes, 119 fossils were not collected because it would need excavation work, which would be impacting to the cave, or for logistical reasons, all of which were identified and counted in situ. A fossil from Gruna das Três Cobras, an individual in an articulated position, was analyzed in situ. This particular material is heavily embedded in a flowstone in a sector with very limited access, so much of the skeleton still in articulated position. This fact prevented the authors from collecting, except for bones that were already broken and fallen on the ground, since its collection would cause great and irreversible damage to the cave. However, the material is protected from weathering and from rainwater or river water, without immediate risk to its integrity. The fossils from Lapa dos Peixes proceed from four sectors: LPI, LPII (a-b), LPIII, LPIV. At Gruna das Três Cobras, the fossils proceed from eight sectors: TCI (a-e), TCII (a-c), TCIII, TCIV (a-c), TCV, TCVI (ac), TCVII, TCVIII (Fig. 11).

Some samples exhibited carbonate incrustations and therefore they were mechanically prepared only enough to allow the observation of diagnostic features, but still keeping part of the incrustations, based on conventional paleontological techniques (Leiggi and May 1994). Fractured samples were bonded with Paraloid B-72 dissolved in acetone. Afterwards, the material was stored in the paleontological collection of Museu de Ciências da Terra, Serviço Geológico do Brasil - CPRM (MCTer, Museum of Earth Sciences, Geological Survey of Brazil), in Rio de Janeiro, Brazil. The samples MCT1864-R to MCT1865-R and MCT3933-M to MCT4210-M proceed from Gruna das Três Cobras (TC) and the samples MCT4211-M to MCT4327-M proceed from Lapa dos Peixes (LP).

The fossils were macroscopically studied and photographed using a digital camera and they were measured using a steel caliper with millimetric accuracy. A measuring tape was used to samples larger than $20 \mathrm{~cm}$. Specimens were identified at the lowest taxonomic level by comparing with literature as well as collections from the Laboratório de Mastozoologia da UNIRIO (LAMAS, Mammalogy Lab at the Federal University of the State of Rio de Janeiro, UNIRIO-PM 6215 to 6229), Museu de Ciências da Terra (MCTer, Serviço Geológico do Brasil CPRM, MCT73-M to 93-M, MCT147-M), Museu de Ciências Naturais, Universidade Federal do Paraná (Museum of Natural Sciences of Federal University of Paraná, MCN.P.631, 632, 634, 636, 638 to 642, 653), and MCN-Museu de Ciências Naturais, Pontifícia Universidade Católica de Minas Gerais (Museum of Natural Sciences of Pontifical Catholic University of Minas Gerais, MCL 4119, 4123, 4264, 4265, $4254,4259,4262,4293,4294,7161$ to $7163,22211,22212,22391$ to 22396, 22426 to 22429, 22244, 22269, 22293, 22379, 22470, 22472, 22681 to $22683,22686,22834-01)$. Photography from many viewpoints and replicas were made in order to help comparing the samples with the material from the abovementioned collections. The general anatomical terminology was based on Paula-Couto (1979), Evans and de Lahunta (2013), ICVGAN - Nomina Anatomica Veterinaria (I.C.V.G.A.N., 2012), Romer and Parsons (1985) and Smith and Dodson (2003). The specific anatomical terms of each taxon are quoted in the comments in the Systematic Paleontology section.

In order to interpret events prior to fossilization, a taphonomic study was performed with 299 specimens from Gruna das Três Cobras and 236 specimens from Lapa dos Peixes, based on Behrensmeyer 


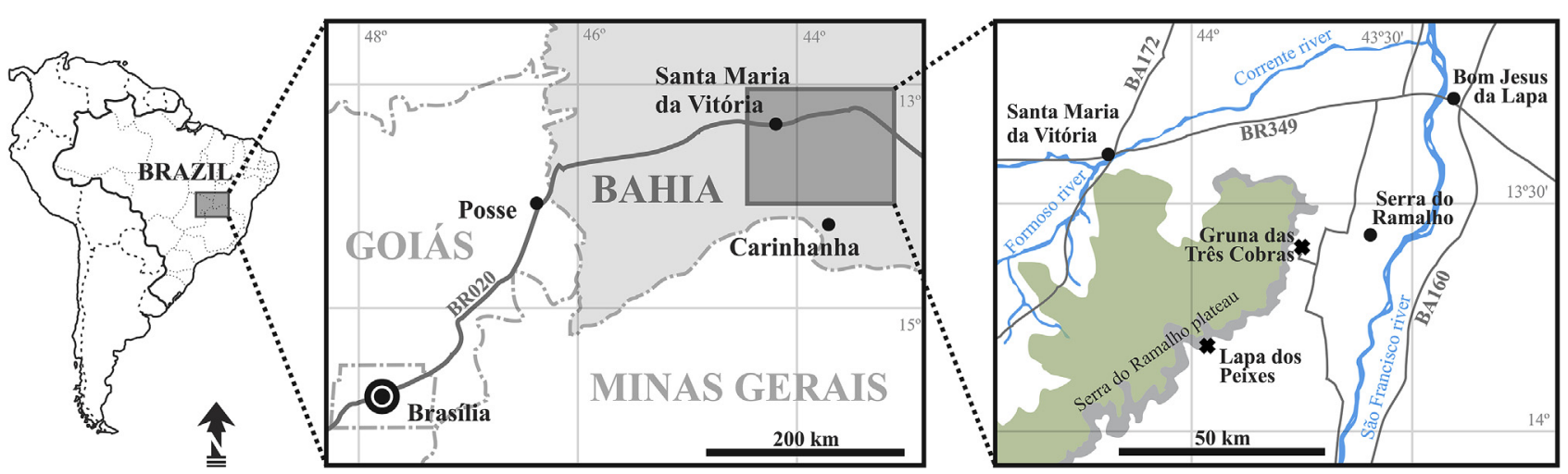

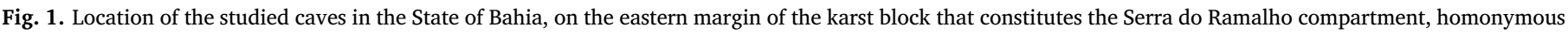
to the municipality.

(1978), Behrensmeyer and Hill (1980), Behrensmeyer et al. (1992), Shipman (1981), Lyman (1994) and Martin (1999). The taphonomic signatures include degree and type of breaks, abrasion and weathering of fossils (Fig. 3). Data on representability of skeletal and taxonomic elements were also considered, as well as the Voorhies groups (Behrensmeyer and Hill, 1980; Shipman, 1981; Lyman, 1994; Martin, 1999) and fluvial transport index for large-sized mammals and megamammals (following Araújo-Júnior et al., 2012). Spearman's nonparametric correlation between FTI values and representability of skeletal elements was performed for the analyzed material through the Paleontological Statistics software (PAST; Araújo-Júnior et al., 2012).

The intensity of breaks in bones were evaluated as follow: absence of breaks, few breaks (up to $50 \%$ in relation to the whole material), and many breaks (more than 50\%). Breaks were classified according to Shipman (1981) as spiral-S, sawtooth-SW, step or columnar-SC, puncture-PU, flaking-FL, scratch-ST, irregular perpendicular-IP, irregular articular-IA and perpendicular smooth-PS. The intensity of abrasion in bones were evaluated as follow: absence of abrasion, few abrasion (up to $50 \%$ in relation to the whole material), and much abrasion (more than $50 \%$ ). The weathering degree was estimated between stages $0-5$ according to Behrensmeyer (1978).

The analysis of breakage in bones made possible to distinguish between pre- and post-fossilization events, that is, breakage occurred prior to burial, herein considered as final burial, and breakage caused by the current erosive processes, which is the main factor responsible for exposing the material (Shipman, 1981; Behrensmeyer et al., 1992; Lyman, 1994). Post-fossilization abrasion and weathering correspond to recent features and therefore were not considered for the interpretation of the depositional environment of fossils. They can be recognized by cutting off older structures as incrustations and mineralized parts of the bones and because they are not mineralized themselves. The marks of pre-fossilization abrasion and weathering are usually filled by mineralized sediment.

In order to understand the processes involving the formation of fossiliferous deposits, pre-fossilization breaks were used additionally to abrasion and weathering to define four taphonomic modes (adapted from Wood et al., 1988; Behrensmeyer et al., 1992; Eberth and Currie, 2005 and Csiki et al., 2010):

- Mode A, bones without significant transportation and little or no pre-fossilization breakage, without abrasion and weathering degree ranging from 0 to 1 ;

- Mode B, bones with significant transportation and pre-fossilization breakage, abrasion varying from few (up to $50 \%$ of the surface) to a much (more than $50 \%$ ) and weathering degree above 1 ;

- Mode C, bones associated with scavenger action, with punctures and flaking;

- Mode D, indeterminate, it is not possible to determine the mode of preservation due to the high degree of post-fossilization breakage.

\section{Geological context}

\subsection{Regional overview}

The Serra do Ramalho region, where the caves are located, consists of a huge pack of mainly carbonate rocks that is one of the most important karstic areas in Brazil (Auler et al., 2001, Figs. 1 and 2C). It forms an extensive plateau that rises between 550 and $780 \mathrm{~m}$ above sea level, elongated in the N-S direction for more than $70 \mathrm{~km}$ between Corrente river (North) and Carinhanha river (South), in the left bank of middle section of São Francisco river (Fig. 1). The region is inserted in the Cerrado Biome and comprises areas included in the municipalities of São Félix do Coribe, Coribe, Cocos, Feira da Mata, Serra do Ramalho and Carinhanha in the Bahia state.

The Serra do Ramalho is sustained by sequences of Neoproterozoic pelitic and carbonate rocks belonging to the Paraopeba Subgroup of Bambuí Group, Jequitaí (not outcropping), Sete Lagoas, Serra de Santa Helena, Lagoa do Jacaré and Serra da Saudade formations (Auler and Farrant, 1996; Bitencourt and Rodet, 2002; Zalán and Silva, 2007), the last one restricted to high elevations in the northernmost part of the plateau (Conceição Filho et al., 2003). Cretaceous sandstones of Urucuia Formation overlay units of Bambuí Group, forming elevated sandy plains which stand out at the plateau summit (Conceição Filho et al., 2003, Fig. 2C).

The stratigraphic column is essentially horizontal, getting geomorphological expression in the erosive levels stepping downward the plateau margins, as well as in the "erosive windows" locally developed within the plateau. The karst features are clearly associated with two carbonate units portrayed by Sete Lagoas and Lagoa do Jacaré formations (calcilutites, calcarenites, calcirudites and dolomites), although other non-carbonate units exert some influence on the active karst processes. The local karst has strongly undulating relief, usually found closed polygonal basins directing the surface runoff into punctual sinks. The surface drainage is typically ephemeral, forming deep-steep incisions. Small to large karren outcrops are scattered as benches, towers and slabs, getting more expressive towards the plateau margins. In several places the plateau is delimited by cliffs with tens of meters height, in whose base are located many springs and ressurgences, shaping stunning landscapes.

\subsection{Description of caves}

Lapa dos Peixes and Gruna das Três Cobras depict respectively a current and a piece of a former karst spring system found in the eastern margin of the Serra do Ramalho block, among dozens of other active and inactive water discharge points. In general, discharges of the 

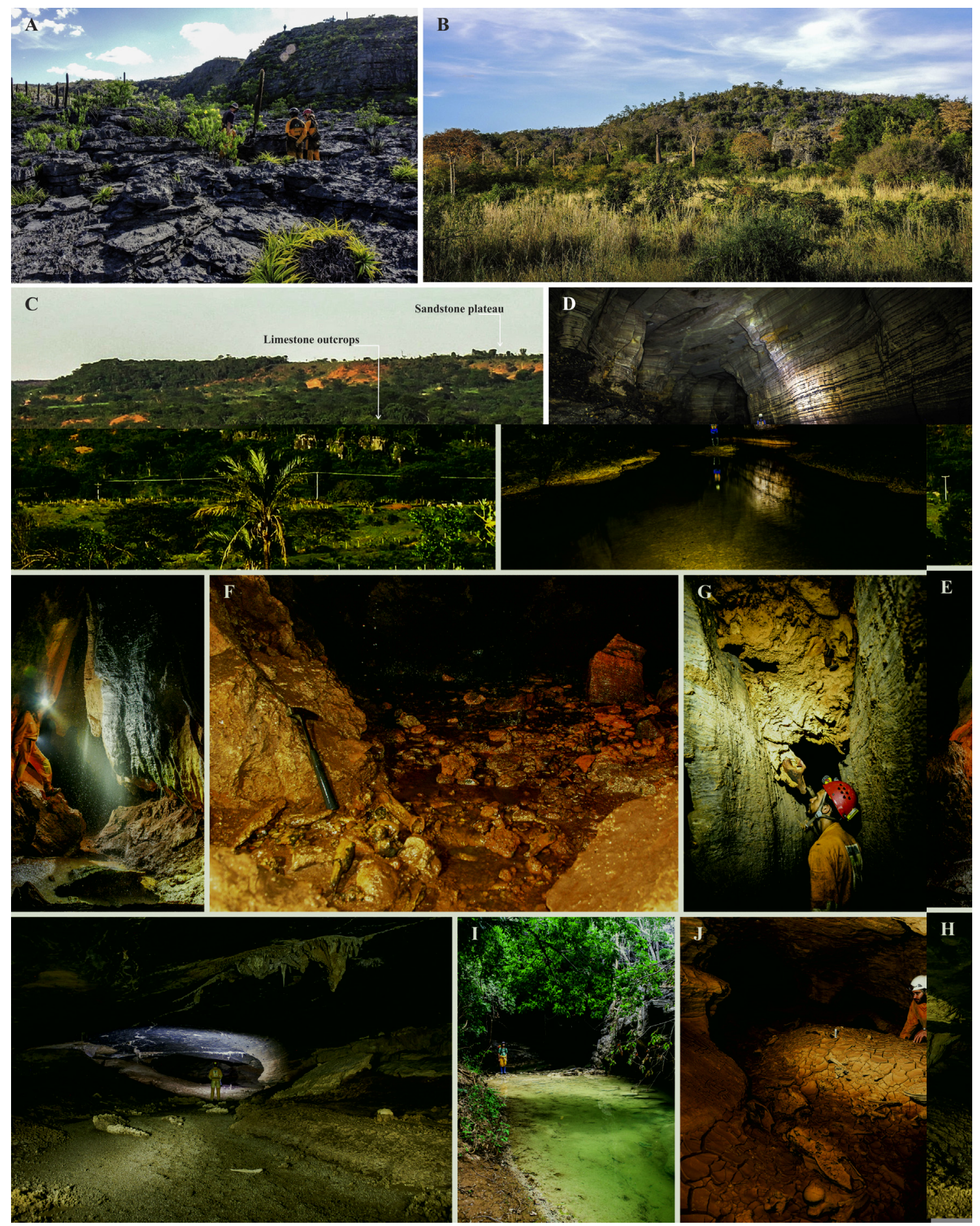

Fig. 2. Main karstic and speleological aspects of the studied region: A) Top of a limestone massif, showing dissolution features and cover deterioration; B) Limestone remnant hill (Maciço do Coração); C) Cretaceous sandstones of Urucuia Formation over Neoproterozoic limestones of Bambuí Group in the highlands of Serra do Ramalho plateau; D) Underground river in large conduit. Gruna das Três Cobras cave: E) Input of rainwater through fissures; F) Exposed and accumulated fossils by pluvial erosion; G) Fossils embedded on stalagmite flowstone with eroded basement. Lapa dos Peixes cave: H) Ancient river channel, now deactivated; I) Active river channel; J) Concentration of fossils exposed by erosion.

underground rivers take place through medium to large conduits (a few meters to a few tens of meters diameter, Fig. 2D) appearing at the foot or at some base-level of peripheral rock massifs. The semi-arid rivers in the Northeastern region of Brazil, where there is a marked and seasonal alternation between drought and rain, usually show great energy during the flood season, but they even dry completely during the drought season. The plateau edges are very karstified areas, maybe the most in the regional karst context. Especially at the more distal (peripheral) portions one can see the overlap of different generations of endogenous karstification or speleogenetic patterns. Often, sets of galleries in labyrinthine anastomosed arrangements are crossed by a main channel. The thinner the rock pack and the groundcover, the more expressive vadose indentation on the set of galleries.

Gruna das Três Cobras presents a horizontal projection of $5620 \mathrm{~m}$ ranging $32 \mathrm{~m}$ vertical according to the map by the Bambuí Group of Speleological Surveys (Sausse, 2013). The cave presents fossiliferous 
A

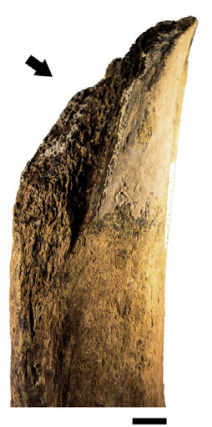

B

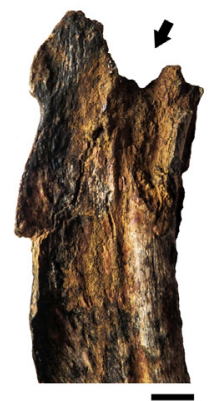

C

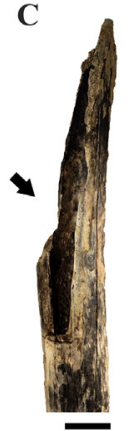

D

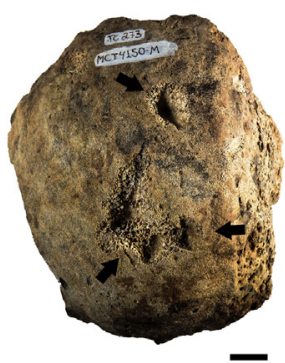

E

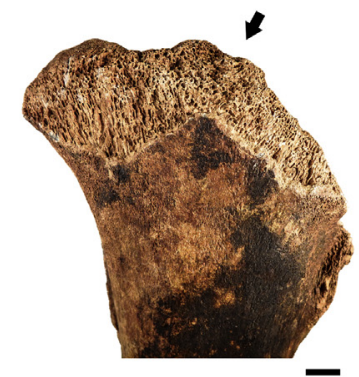

F

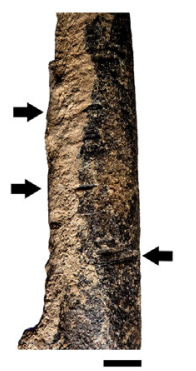

G

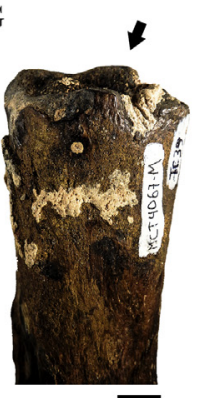

H

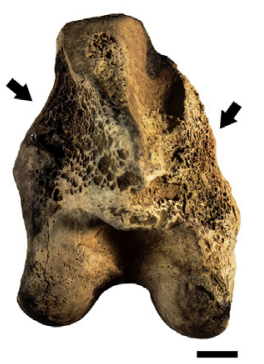

I

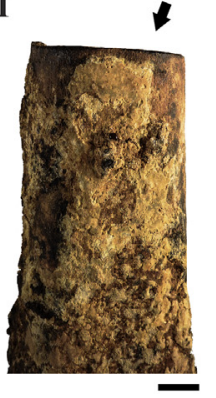

$\mathbf{J}$

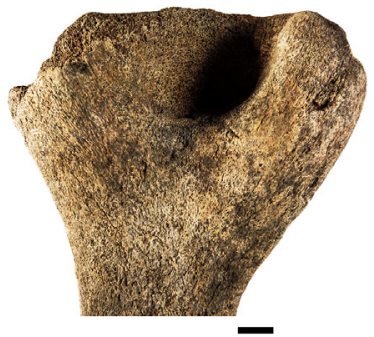

$\mathbf{K}$

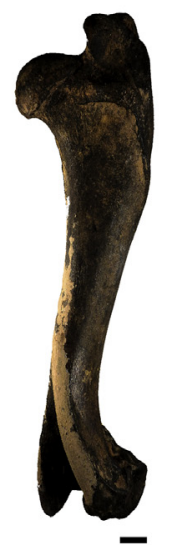

L

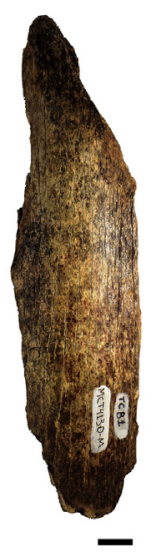

M

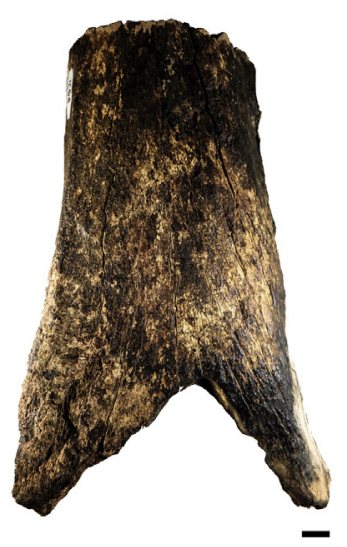

$\mathbf{N}$

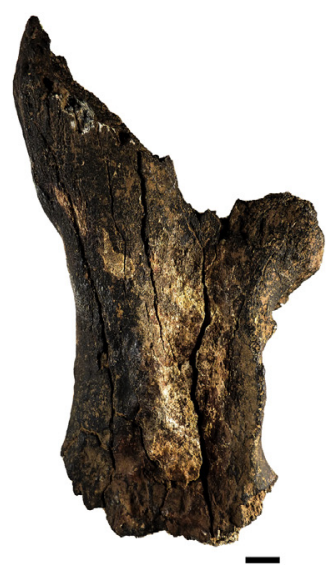

Fig. 3. Taphonomic features observed in bones. A) Spiral breaks; B) Sawtooth breaks; C) Step or columnar breaks; D) Punctures; E) Flaking; F) Scratches; G) Irregular perpendicular breaks; H) Irregular articular breaks; I) Perpendicular smooth breaks; J) Abrasion; K) Weathering degree stage 0; L) Weathering degree stage 1; M) Weathering degree stage 2; N) Weathering degree stage 3.

sedimentary deposits formed by fine to coarse and poorly sorted silty sand, periodically eroded by rain runoff (Fig. 2E). The maze-like feature with several entrances and the deeper galleries on the subsurface surroundings, added to the dissolution fissures connected to the massif top, enhance the input of water into the cave and the outflow. As a result, the finer sediments are carried to greater depths, leaving larger bones and clasts accumulated in the eroded portions, usually with little or no transportation but not in articulated position (Fig. 2F). Due to seasonal (vadose) water activity, more fossils are revealed each rainy season. There are also fossils embedded in hanging calcite layers (Fig. 2G).

Lapa dos Peixes, with horizontal projection of $7020 \mathrm{~m}$ and $14 \mathrm{~m}$ vertical range (Bitencourt and Rodet, 2002; Bichuette and Rizzato, 2012), shows a pattern of meandering conduit linked to a river subjected to extreme oscillations of discharge flows, with side compartments which become active under overflow conditions. Sedimentary deposits formed by fine to coarse and poorly sorted silty sand, periodically eroded by rain runoff, occur throughout the entire cave, in a context similar to Gruna das Três Cobras. Regarding to current hydrological dynamics and evolutionary condition, the cave can be subdivided into two sections: a) downstream segment, partially flooded by a main river which flow volumes varies seasonally, becoming quite reduced during droughts then leaving temporary pools in points of the gallery (Bichuette and Rizzato, 2012); and b) upstream segment in which galleries were almost left behind by the main river due to course realignment (Fig. 2H), except for the occurrence of restricted infiltrations of vadose water linked to discharges which are not supported by the flow capacity downstream.

In the upstream section, the river currently flows externally circling the massif (Fig. 2I). This part of the cave presents greater morphological and geometric diversity and complexity, characterized by the intersection of sets of galleries with reticulated and anastomosed labyrinthine patterns. The morphology, arrangement, detrital materials and other waterprints in chambers and conduits of this cave section reveal oscillations of groundwater level, with open flooding in some portions. On the other hand, in this section there is also greater exposure to pluvial processes and associated erosion, given the small thickness and 


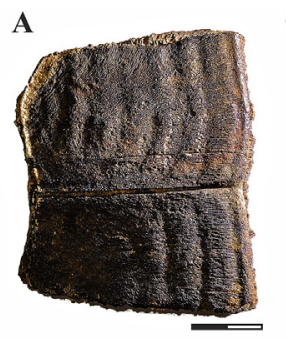

B

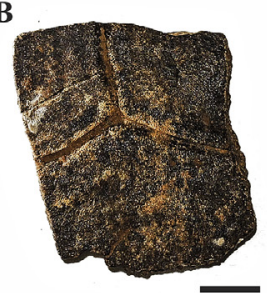

J

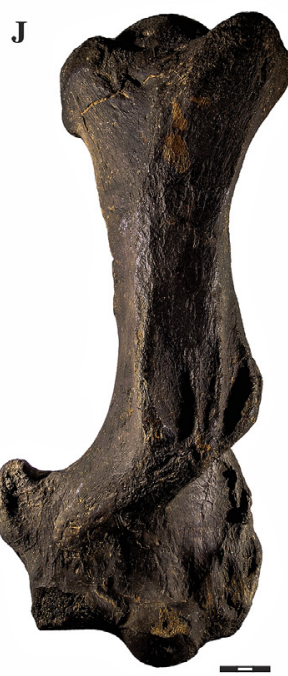

C

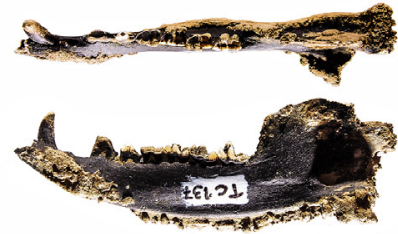

D

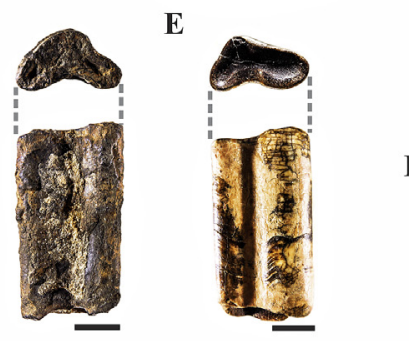

K
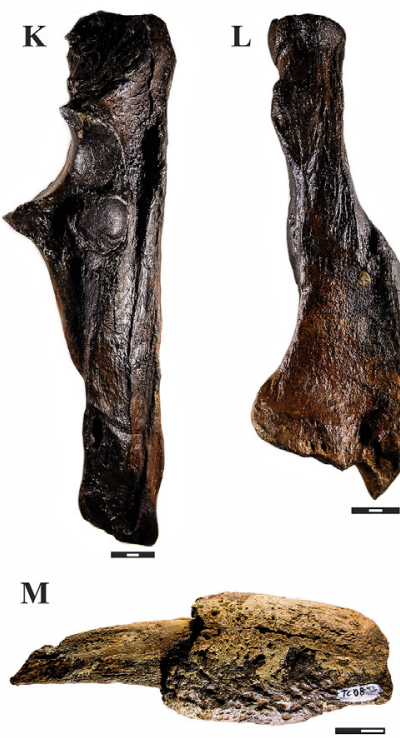

G

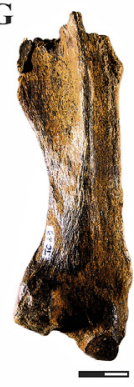

H

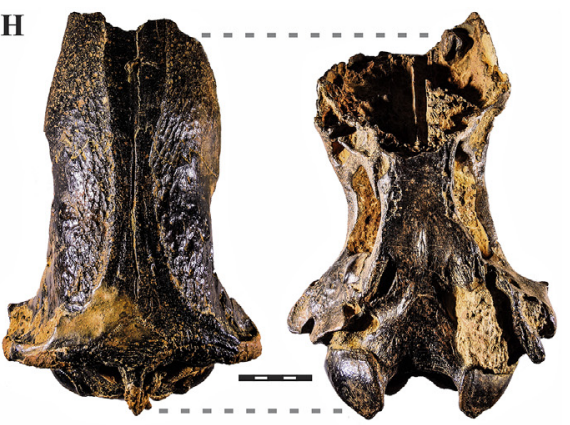

F
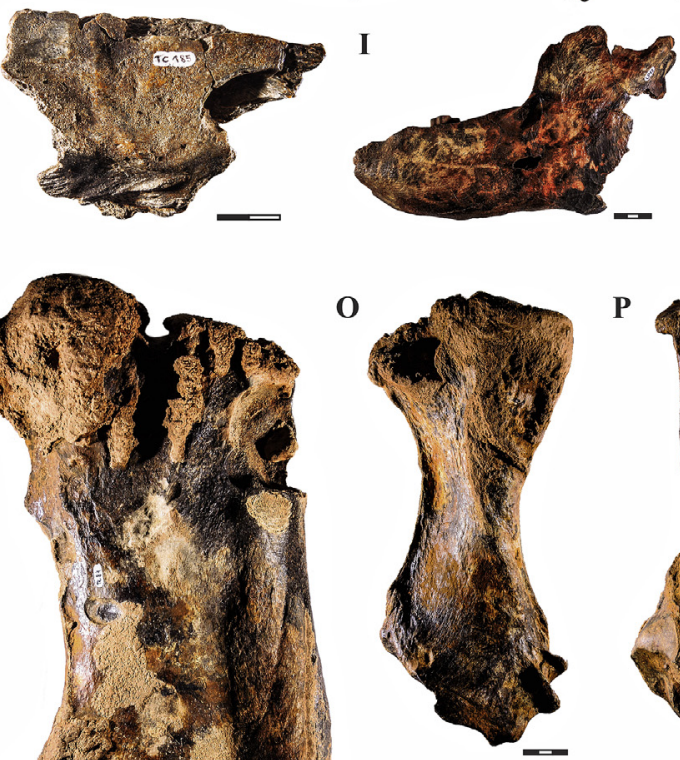

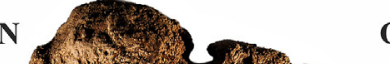

N

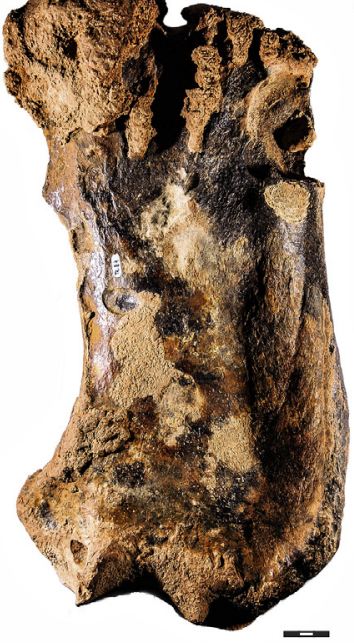

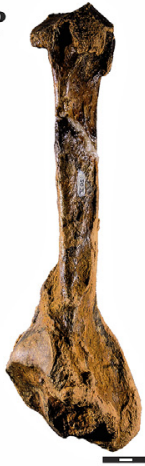

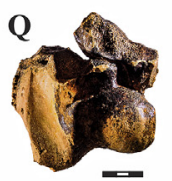

$\mathbf{R}$

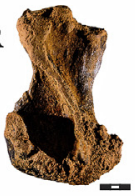

Fig. 4. Chelonoidis sp.: A) MCT1864-R, dorsal view of peripheral plate; B) MCT1865-R, dorsal view of proximal fragment of the costal plate. Didelphis sp.: C) MCT3933-M, medial view of right dentary. Scelidotheriinae: D) MCT4248-M, M5 in occlusal and posterior view; E) MCT3971-M, m2 in occlusal and posterior view; F) MCT3969-M, lateral view of squamosal and alisphenoid; G) MCT3966-M, sternal rib in ventral view. Catonyx cuvieri: H) MCT3951-M, incomplete skull in dorsal and ventral view; I) MCT4244-M, left dentary in lateral view; J) MCT4211-M, anterior view of left humerus; K) MCT3953-M, lateral view of left ulna; L) MCT3954-M, lateral view of left radius; M) MCT3939-M, lateral view of ungual phalanx; N) MCT3947-M, anterior view of left femur; O) MCT3942-M, anterior view of left tibia; P) MCT3937-M, anterior view of right fibula; Q) MCT3936-M, dorsal view of left astragalus with navicular; R) MCT3935-M, dorsal view of left calcaneus. Scale in centimeters.

high degree of karstification of the rock above the cave, which expose fossils (Fig. 2J).

\section{Results and discussion}

\subsection{Systematic Paleontology}

Order Testudines Linnaeus, 1758

Family Testudinidae Batsch, 1788

Genus Chelonoidis Fitzinger, 1835

Chelonoidis sp. (Fig. 4A and B)

Material: MCT1864-R, peripheral plate; MCT1865-R, proximal fragment of costal plate.

Comments: In dorsal view, the peripheral plate shows a groove, laterally displaced, deeper and narrower than the costal plate, which represents the limit of two epidermal scutes, and concentric growth marks. The costal plate, in dorsal view, has a "Y" shaped groove in the contact of two pleural and vertebral scutes. The plates show characters as the flat shape, thickness of plates and lack of lateral keel, which have allowed to attribute the specimens to Testudinidae family (e.g. Manzano et al., 2009). They also have a similar morphology to Chelonoidis ( = Geochelone, Le et al., 2006) in comparison to extant specimens of from MCTer (not numbered, reference collection), although the studied material presents a significantly larger size. This genus corresponds to terrestrial turtles widely distributed in South America (e.g. Manzano et al., 2009). Large specimens were recorded in the Pleistocene of Argentina, but in Brazil they are still little known. There are occurrences of the genus in the Pleistocene of the states of Rio Grande do Sul, Piauí, Sergipe and Rondônia (Maciel et al., 1996; Guerin et al., 2002; Lôbo et al., 2007; Andrade et al., 2017).

Order Didelphimorphia Gill, 1872

Family Didelphidae Gray, 1821

Genus Didelphis Linnaeus, 1758

Didelphis sp. (Fig. 4C)

Material: MCT3933-M, right mandibular ramus.

Comments: Incomplete right mandibular ramus, lacking angular and coronoid processes, dental series missing only the first two incisors. The premolars are sharp to grinders, the molars are hexacuspid with 
trigonid higher than talonid. The dental formula is i 4 , c $1, \mathrm{pm} \mathrm{3,} \mathrm{m} 4$. The mandible presents dimensions compatible with Didelphis (e.g. Winge, 1915; Paula Couto, 1979; Mohamed, 2018), being greater than the other South American marsupials, however is not sufficient to be determined at species level. There are occurrences of the genus in the Pleistocene of the states of Minas Gerais, Bahia, Ceará and Goiás (Cartelle, 1999; Nova et al., 2015).

Order Pilosa Flower, 1883

Family Mylodontidae Ameghino, 1889

Subfamily Scelidotheriinae Ameghino, 1904

Scelidotheriinae indet. (Fig. 4D-G)

Material: MCT4248-M, M5; MCT3972-M, m5; MCT3971-M, m2; MCT3969-M, squamosal and alisphenoid; MCT3968-M, axis; MCT3965M, hemal arch; MCT4251-M, MCT4252-M, thoracic vertebrae; MCT3967-M, МСT3970-M, MCT3975-M, clavicle; MCT3966-M, sternal rib; MCT4247-M, МСT3974-M, rib; MCT4253-M, metacarpal V; MCT4246-M, MCT4249-M, metatarsal III; MCT4245-M, MCT4250-M, metapodials; MCT3973-M, middle phalanx of digit IV.

Comments: The specimen MCT3969-M is a cranial fragment with portions of squamosal and alisphenoid in which the superior orbital fissure has the same shape as in scelidotheriines such as Catonyx and Valgipes, but it is not possible to distinguish between them. The M5 and $\mathrm{m} 2$ teeth are subtriangular, but it is not possible to determine whether of the left or right side. The metatarsals III are short bones with robust crest on dorsal surface. In the middle phalanx of digit IV, the distal articular surface is reel shaped, transversally narrower than the rest of the bone. The other elements are similar to the subsequent Scelidotheriinae materials identified at species level, however it was not possible to determine at genus or species level due to the lack of diagnostic features.

Genus Catonyx Ameghino, 1891

Catonyx cuvieri Lund, 1839 (Fig. 4H-R)

Material: МСT3951-M, incomplete skull; MCT4244-M, left dentary; MCT4212-M, right dentary; MCT3961-M, lower molariform; MCT3955$\mathrm{M}$, right m4; МСТ3956-M, right m1; МСТ3946-M, axis and cervical vertebrae; МСТ3948-M, МСТ3949-M, thoracic vertebrae; МСT3945-M, MCT3959-M, МСТ3960-M, caudal vertebrae; МСT3952-M, MCT4211M, left humerus; МСТ3944-M, МСТ3953-M, left ulna; MCT4214-M, МСТ3943-M, right ulna; МСТ3938-M, МСТ3954-M, left radius; MCT3940-M, MCT3958-M, middle phalanges from metatarsal III; MCT3939-M, ungual phalanx; MCT3947-M, МCT3957-M, MCT4215-M, left femur; MCT3942-M, left tibia; MCT3937-M, right fibula; МСТ3936M, left astragalus with navicular; МСT3950-M, right astragalus; MCT3935-M, left calcaneus; MCT4213-M, MCT4216-M, navicular; MCT3941-M, phalanx from pes.

Comments: The material was determined as C. cuvieri for presenting characteristics consistent with those cited by Corona et al. (2013) and Cartelle et al. (2009), such as dolichocephalic skull with temporal lines, divided by a thin sagittal suture, delimiting the concave surface in the parietal; occipital condyles projected for ventral region; presence of a fine crest in the basioccipital-basisphenoid midline. The mandibular body is tapered anteriorly in the dorso-ventral direction. The lower teeth are very similar among the Scelidotheriinae, but the lingual surface of $\mathrm{m} 1$ is concave in C. cuvieri. Humerus without entepicondylar foramen, differing from Valgipes. Ulnas with robust olecranon with dorsal surface considerably rough; anterior margin of olecranon is lateromedially compressed and goes from the olecranon tuberosity to the anconeal process, forming a robust crest; the anconeal process is short and slightly tilted and distally articulates with the trochlear notch. Radius with distal half of radial axis medially deflected and flat and straight ungual phalanx. Parallelogram shaped femur anteroposteriorly flattened with patellar facet continuous with lateral and medial condyles. Tibia and fibula not merged at proximal and distal ends. This species is found in Bahia, Minas Gerais, Piauí, Ceará, Paraíba, Sergipe, São Paulo, Paraná and Rio Grande do Sul (Cartelle et al., 2009; Dantas and Zucon, 2007; Paula-Couto, 1973; Sedor et al., 2004; Lopes and Pereira, 2010).

Genus Valgipes Gervais, 1874

Valgipes bucklandi Lund, 1839 (Fig. 5A-I)

Material: MCT3993-M, MCT4271-M, MCT4272-M, skulls; MCT4260-M, right M2; MCT3996-M, right M4?; MCT4266-M, axis; MCT4263-M atlas; MCT4254-M, cervical vertebra; MCT3989-M, MCT3990-M, thoracic vertebrae; MCT3977-M, sacral vertebrae; MCT4281-M, MCT3979-M, MCT3980-M, caudal vertebrae; MCT3992M, MCT4262-M, MCT3976-M, MCT3991-M, scapula; MCT4280-M, clavicle; MCT4261-M, MCT4264-M, right humerus; MCT3981-M, left ulna; MCT3986-M, MCT3982-M, right ulna; MCT4267-M, right radius; MCT4269-M, left radius; MCT4276-M, right metacarpal IV; MCT4259M, metacarpal V ?; MCT3978-M, medium phalanx; MCT3985-M, MCT3987-M, MCT4255-M, MCT4258-M, MCT4265-M, MCT4268-M, ungual phalanges; MCT3988-M, MCT4279-M, MCT4282-M, pelvic girdle; MCT3984-M, ileum; MCT4273-M, right femur; MCT4274-M, patella; MCT4270-M, right tibia-fibula; MCT4275-M, right fibula; MCT4257-M, left calcaneus; MCT4278-M, right calcaneus; MCT4283M, navicular; MCT4277-M, MCT3983-M, metatarsal IV; MCT4256-M, metatarsal V; MCT3995-M, metatarsal III phalanx; MCT3994-M, osteoderm.

Comments: It was identified as $V$. bucklandi for presenting diagnostic features described by Cartelle et al. (2009), as follow. The superior dentition shows triangular section except for M1. Clavicle with proximal portion enlarged and flattened, thin body and distal portion with convex articular surface. The proximal portion of scapula merges forming a bridge. Humerus with entepicondylar foramen. Ulna is elongated, narrow and curved. Ungual phalanges are curved, lateromedially compressed and covered by ungual crest. Fibula and tibia merged at proximal-medial and distal-medial ends. Metatarsus V (MCT4256-M) without projection in the distal portion, as in V. bucklandi defined by Cartelle et al. (2009). Other characteristics mentioned by Cartelle et al. (2009), such as cranial constrictions, foramen openings and superior dentition, are in agreement with those observed. Valgipes bucklandi is endemic to the Intertropical Region of Brazil, occurring in other municipalities of Bahia, Minas Gerais, Piauí and Rio Grande do Norte (Cartelle et al., 2009; Guérin and Faure, 2004).

Family Nothrotheriidae Ameghino, 1920

Genus Nothrotherium Lydekker, 1889

Nothrotherium maquinense Lund, 1839 (Fig. 5J-N)

Material: MCT4229-M, skull; MCT4232-M, MCT4243-M, incomplete mandible; MCT4225-M, MCT4235-M, MCT4240-M, caudal vertebrae; MCT4234-M, MCT4242-M, lumbar vertebrae; MCT4226-M, MCT4237-M, vertebrae; MCT4222-M, MCT4223-M, ribs; MCT4233-M, sacrum fragment; MCT3964-M, right humerus fragment; MCT4241-M, distal portion of left humerus; MCT4218-M, distal portion of right humerus; MCT4224-M, MCT4236-M, proximal portion of right ulna; MCT4238-M, proximal portion of left ulna; MCT4239-M, left radius; MCT4221-M, MCT4228-M, right radius; MCT4231-M, pelvic girdle with acetabulum; MCT4217-M, distal portion of left femur; MCT4219-M, proximal portion of left femur; MCT4230-M, right femur; MCT4220-M, proximal portion of right femur; MCT4227-M, right tibia.

Comments: The material was determined as $N$. maquinense based in characteristics described by Paula-Couto (1959) and Cartelle and Fonseca (1983), such as the following. It presents an elongated, tubularshaped skull, with poorly marked temporal lines. The mandible has three molariforms of nearly quadrangular shape in occlusal view, in which labial and mesial faces are longer; the symphysis extends anteriorly, scoop shaped. Humerus with enlarged distal portion and evident entepicondylar foramen. Ulnas are narrow and elongated, quadrangular in section, with proportionally small olecranon. The radius is slightly curved in its distal half. The femurs are large and anteroposteriorly flattened, with distal articular facets separated. The tibia is curved and robust at extremities, with no procnemial crest. The morphology of $N$. maquinense is well known through quite complete skeletons (e.g. PaulaCouto, 1959; Cartelle and Fonseca, 1983), matching with the studied 

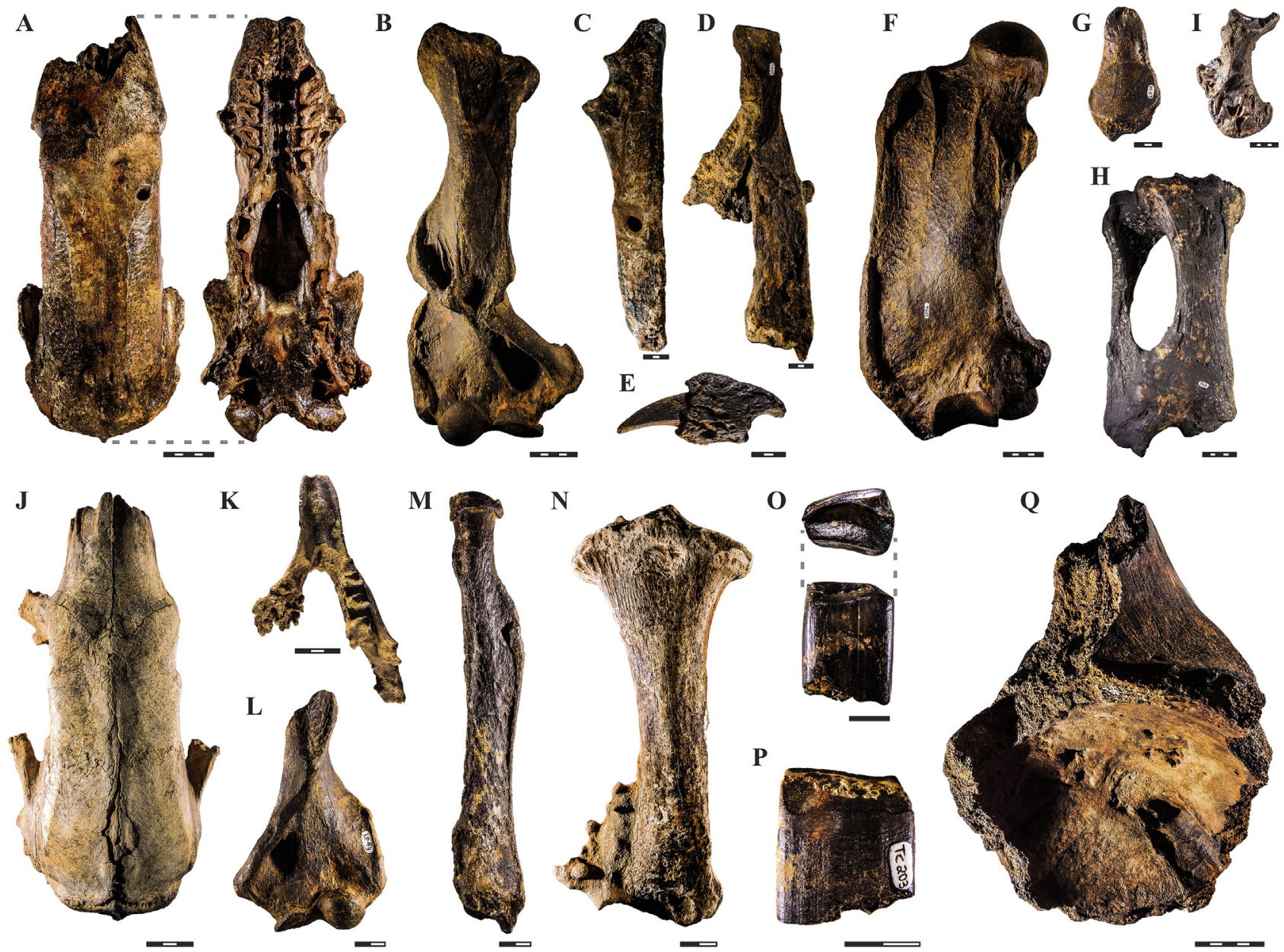

Fig. 5. Valgipes bucklandi: A) MCT3993-M, skull in dorsal and ventral view; B) MCT4264-M, anterior view of right humerus; C) MCT3986-M, medial view of right ulna; D) MCT4267-M, medial view of right radius; E) MCT4268-M, lateral view of ungual phalanx; F) MCT4273-M, anterior view of right femur; G) MCT4274-M, dorsal view of patella; H) MCT4270-M, anterior view of right tibia-fibula; I) MCT4278-M, dorsal view of right calcaneus. Nothrotherium maquinensis: J) MCT4229-M, dorsal view of skull; K) MCT4232-M, dorsal view of incomplete mandible; L) MCT4241-M, anterior view of incomplete left humerus; M) MCT4228-M, anterior view of right radius; N) MCT4227-M, anterior view of right tibia. Megalonychidae: O) MCT3934-M, right M2 in occlusal and posterior view. Megatheriidae: P) MCT3962$\mathrm{M}$, molariform in anterior or posterior view; Q) MCT4149-M, pelvic girdle fragment. Scale in centimeters.

material. This species is found in Ceará, Rio Grande do Norte, Bahia, Minas Gerais and São Paulo (e.g. Paula-Couto, 1959; Cartelle and Fonseca, 1983; Araújo-Júnior and Porpino, 2011).

Family Megalonychidae Gervais, 1855

Megalonychidae indet. (Fig. 50)

Material: MCT3934-M, right M2.

Comments: M2 with subtriangular cross-section. The lingual face is longer than labial, while mesial face is curved, and distal face is convex. The occlusal face presents two crests at mesial and distal margins merged at the lip border, with a central depression. Dimensions and morphological characteristics are consistent with Ahytherium aureum described by Cartelle et al. (2008; specimen MCL 22834-01 from MCN collection), but an isolated molariform tooth is not very diagnostic for a species assignation, so a designation at family level is maintained.

Family Megatheriidae Owen, 1843

Megatheriidae indet. (Fig. 5P and Q)

Material: MCT3962-M, fragment of molariform; MCT4149-M, fragment of pelvic girdle.

Comments: The material shows characters and size compatible with Megatheriidae (following Cartelle and De Iuliis, 1995) as prismatic molariform of quadrangular longitudinal section, mesiodistally flattened; convex distal face with distal crest preserved. Pelvic girdle with deep acetabulum and elongated acetabular fossa. Eremotherium laurillardi is considered to be the only species of Megatheriidae present in
Bahia and thus in the Pleistocene of the Intertropical Region (Cartelle and De Iuliis, 1995; Cartelle et al., 2014), in which the studied region is inserted. However, the material studied does not allow the distinction between Eremotherium and Megatherium, the material then attributed to Megatheriidae. The material also matches with already mentioned specimens from MCN-UFPR, identified as Megatheriidae.

Order Cingulata (Illiger, 1811).

Family Pachyarmateriidae Fernicola et al., 2018

Genus Pachyarmatherium Downing and White, 1995

Pachyarmatherium brasiliense Porpino et al. (2009) (Fig. 6A and B)

Material: MCT4035-M, MCT4285-M, buckler osteoderms.

Comments: The material was determined as $P$. brasiliense based in characteristics described by Porpino et al. (2009), Dantas (2012) and Costa Pereira et al. (2014), such as the hexagonal osteoderms with subrounded to polygonal central figure, not entirely surrounded by four to five peripheral figures and two pits at the intersection of main and radial sulci. In Brazil, this taxon was recorded in Rio Grande do Norte, Pernambuco, Tocantins and Rio Grande do Sul states (e.g. Porpino et al., 2009; Dantas et al., 2011; Dantas, 2012; Oliveira et al., 2013; Soibelzon et al., 2015).

Family Dasypodidae Gray, 1821

Genus Propraopus Ameghino, 1881

Propraopus sulcatus Lund, 1838 (Fig. 6C)

Material: MCT4036-M: movable band osteoderm. 
A

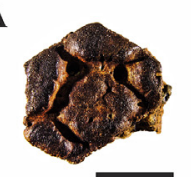

B

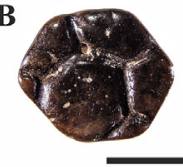

I

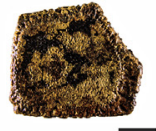

J

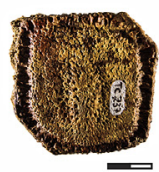

K

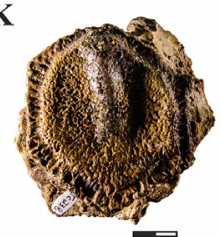

Q

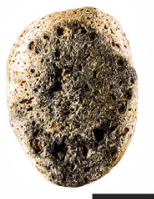

C

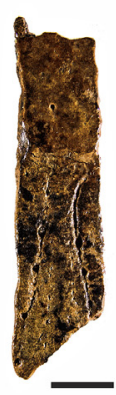

D

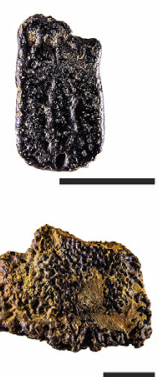

L

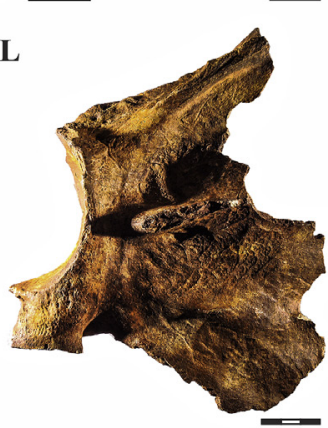

M

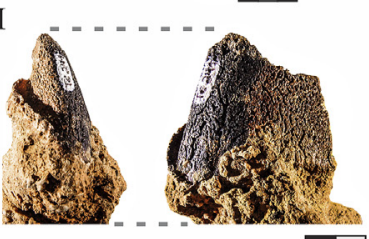

$\mathbf{R}$

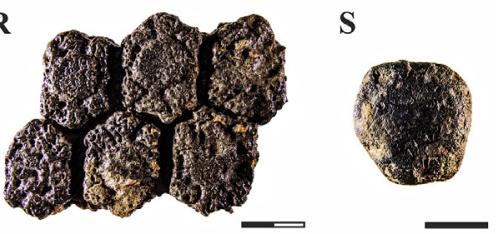

$\mathbf{F}$

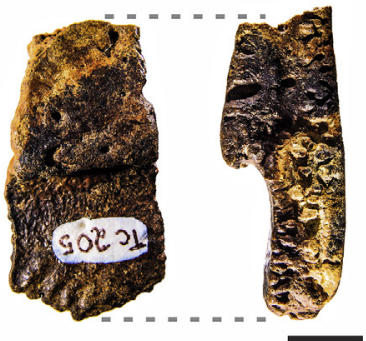

G

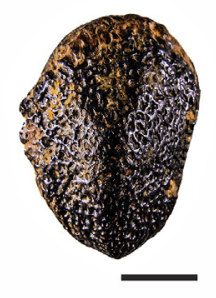

H

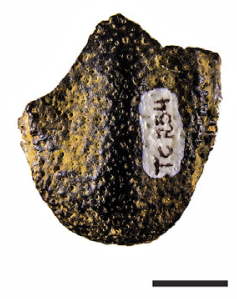

$\mathbf{N}$

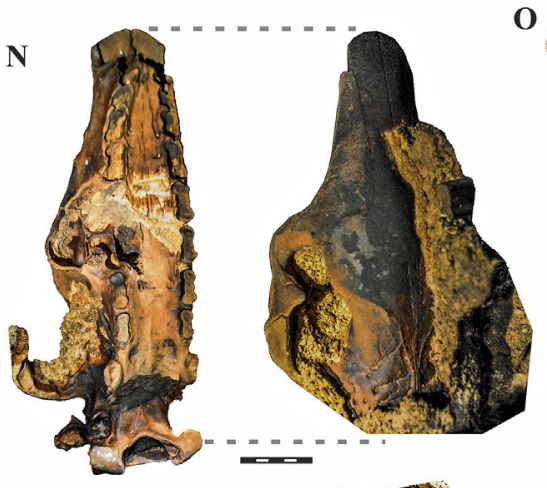

O

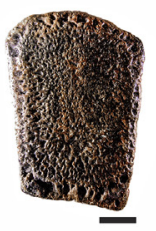

$\mathbf{P}$

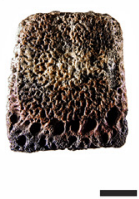

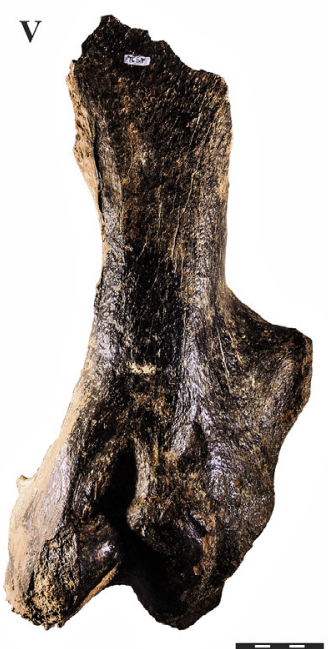

Fig. 6. Pachyarmatherium brasiliense: A) MCT4035-M, dorsal view of buckler osteoderm; B) MCT4285-M, dorsal view of buckler osteoderm. Propraopus sulcatus: C) MCT4036-M, dorsal view of movable band osteoderm. Euphractus sexcinctus: D) MCT4006-M, dorsal view of movable band osteoderm. Holmesina sp.: E) MCT4016-M, dorsal view of buckler osteoderm; F) MCT4014-M, dorsal and anterior view of movable band osteoderm; G) MCT4015-M, dorsal view of manus/pes osteoderm; H) MCT4017-M, dorsal view of caudal osteoderm. Holmesina majus: I) MCT4023-M, dorsal view of buckler osteoderm; J) MCT4026-M, dorsal view of buckler osteoderm; K) MCT4027-M, dorsal view of buckler osteoderm; L) MCT4260-M6, dorsal view of incomplete right scapula; M) MCT4029-M, lateral and dorsal view of ungual phalanx; N) ventral, dorsal and lateral view of skull in situ. Pampatherium sp.; O) MCT4286-M, dorsal view of buckler osteoderm; P) MCT4287-M, dorsal view of buckler osteoderm. Glyptotherium sp.: Q) MCT4009-M, dorsal view of lateral buckler osteoderms; R) MCT4011-M, dorsal view of lateral buckler osteoderms; S) MCT4010-M, dorsal view of buckler osteoderm; T) MCT4012-M, dorsal view of buckler osteoderm; U) MCT4013-M, dorsal view of osteoderm; V) MCT4007-M, anterior view of incomplete left femur. Scale in centimeters.

Comments: It was identified as $P$. sulcatus for presenting diagnostic features described by Castro (2009) and Castro et al. (2013), such as elongated osteoderm with smooth and rectangular horizontal depression occupying $1 / 3$ the osteoderm length. The ornate portion has a lageniform central figure separated from the two peripheral figures by curved sulci, with five foramina in each sulcus. The number of foramina and sulcus shape of the studied material allows to distinguish it from Dasypus. Specimens of Propraopus sulcatus were also recorded in the states of Tocantins, Minas Gerais, Bahia, Piauí, Mato Grosso and Rio Grande do Sul (Castro et al., 2013; Soibelzon et al., 2015).

Euphractus sexcinctus Linnaeus, 1758 (Fig. 6D)

Material: MCT4006-M: movable band osteoderm.

Comments: Despite the fragmentary character of the material, it can be determined as $E$. sexcinctus for features as rectangular osteoderm with lenticular and elongated central figure surrounded by two sulci; several foramina of hair follicles are present at the distal end and at sulci, the largest one is at the base of central figure. In the dorsal portion it is possible to observe part of the rugose depression. These characteristics easily differ from other Dasypodidae, in which sulci are divergent (e.g. Winge, 1915; Oliveira et al., 2014; Soibelzon et al., 2015). There are Pleistocene records of this taxon in the states of Acre, Bahia, Mato Grosso do Sul, Minas Gerais, Piauí, Rio Grande do Sul and São Paulo (Cartelle, 1999; Oliveira et al., 2014).

Family Pampatheriidae Paula Couto, 1954

Genus Holmesina Simpson, 1930

Holmesina sp. (Fig. 6E-H)

Material: MCT4016-M, buckler osteoderm; MCT4014-M, movable band osteoderm; MCT4185-M, osteoderm; MCT4015-M, manus/pes osteoderm; MCT4017-M, caudal osteoderm.

Comments: The material can be determined as Holmesina based in the following characters. The osteoderms have a similar pattern of rugosity on the external surface, densely punctuated. When present, the central figure is higher with a crest bordered by two gentle depressions. The marginal area is large, shallow and rugose. The manus/pes osteoderm is characteristically triangular, with a strong crest and a narrow and depressed margin. The caudal osteoderm has a rounded margin and central figure with the same characteristics. The material has characteristics similar to Holmesina as shape and texture of central figure, 
A

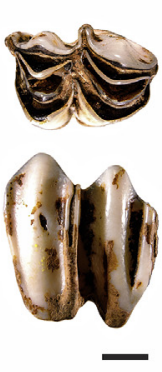

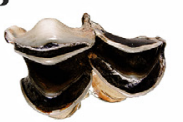

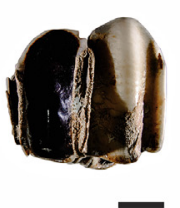

C
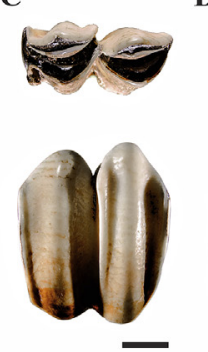

M
I

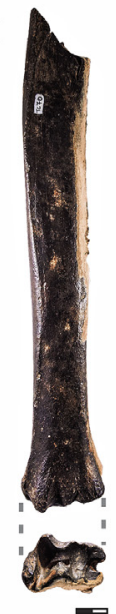

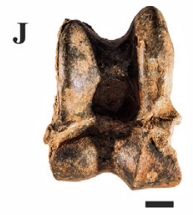

K

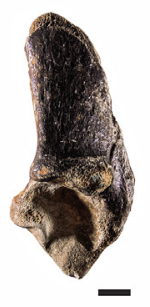

$\mathbf{L}$

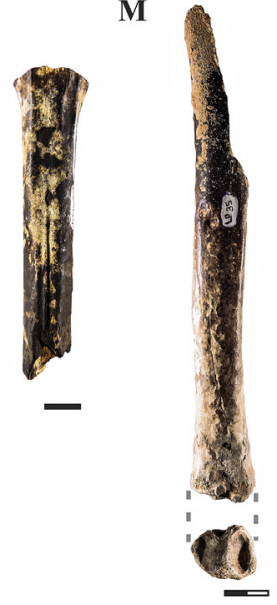

D

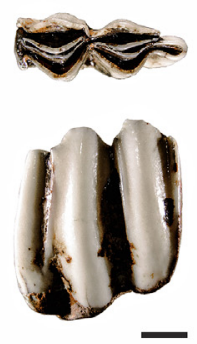

E

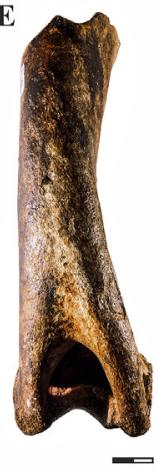

F

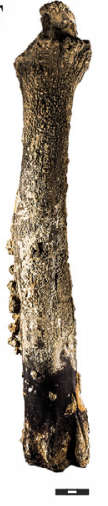

G

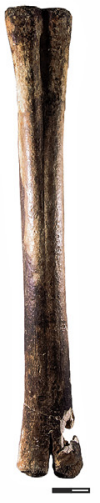

H

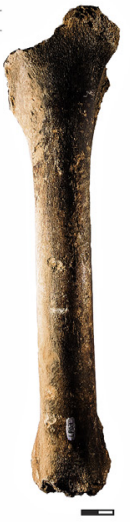

N

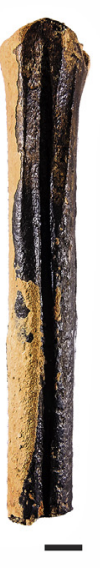

$\mathbf{O}$

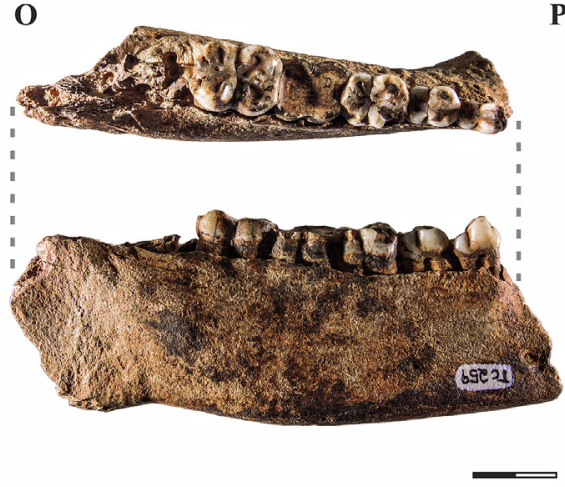

$\mathbf{P}$

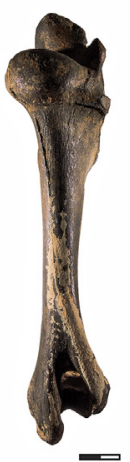

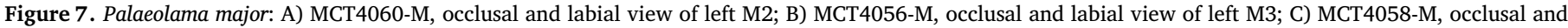

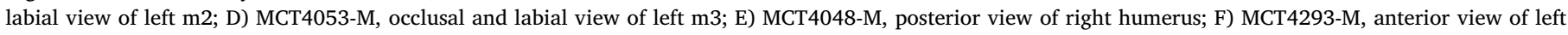

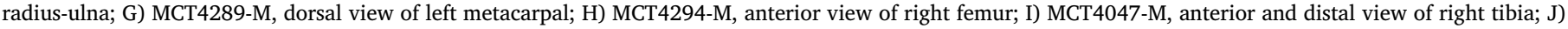

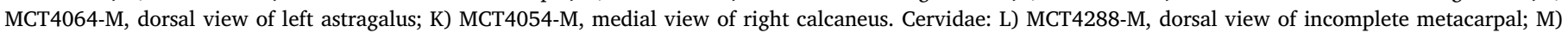

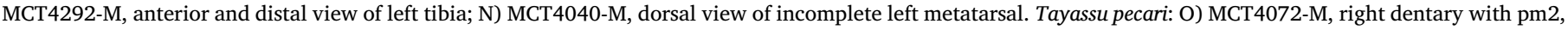
pm3, pm4, m1 and m2 in occusal and lateral view; P) MCT4071-M, posterior view of right humerus. Scale in centimeters.

margin size and depth. The depressed margin and the central figure crest allow to separate it from Pampatherium (e.g. Cartelle and Bohórquez, 1984; Scillato-Yané et al., 2005). However, due to the material fragmentary nature and lack of specific information, it was maintained the determination at genus level. Holmesina occurs in states of Bahia, Rio Grande do Sul, Rondônia, Minas Gerais and Ceará (Cartelle, 1999; Oliveira and Kerber, 2009; Góis et al., 2012).

Holmesina majus (Lund, 1842) (Fig. 6I-N)

Material: MCT4023-M, MCT4024-M, MCT4026-M, MCT4027-M, MCT4031-M, MCT4034-M, MCT4030-M, buckler osteoderms; MCT4018-M, incomplete right scapula; MCT4020-M, left sternal rib; MCT4022-M, medium phalanx; MCT4025-M, right clavicle; MCT4032M, MCT4033-M, pelvic girdle fragment; MCT4019-M, ilium fragment; MCT4028-M, metapodial; MCT4029-M, ungual phalanx. Other remaining specimens of a skeleton in articulated position remain in situ, including skull, vertebrae, ribs, large osteoderms and bones of locomotory appendages.

Comments: The material can be determined as $H$. majus by the following characters. The dentition is homodont, with evident bilobation from MF4 to MF9 and short interdental spaces. Overlap occurs between MF2-MF4, but without contact. The osteoderms are larger over others herein studied and have diverse polygonal shapes with rugose and punctate external surface. The central figure is higher with a large crest bordered by depressions. The margin is quite depressed and rugose. The ungual phalange is short, dorsoventrally flattened and slightly curved. Some osteoderms features as the less rugose surface, larger central figure crest bordered by deeper depressions and more depressed border allow to separate it from Pampatherium and other Holmesina species (e.g. Cartelle and Bohórquez, 1984; Scillato-Yané et al., 2005). This species occurs in states of Minas Gerais and Ceará (Góis et al., 2012).

Genus Pampatherium Ameghino, 1875

Pampatherium sp. (Fig. 6O-P)

Material: MCT4286-M, MCT4287-M, buckler osteoderms.

Comments: MCT4286-M is a pentagonal to rectangular osteoderm with punctuated surface and narrow, depressed and rugose margin. The central figure has a smooth and wide elevation. The specimen MCT4287-M is rectangular, flat, central figure without elevation, with punctuated surface and low depressed margin on one side. These characters are typical of Pampatherium. The absence of crests and significant depressions in the central figure as well as the narrow margin allow differentiating the material of Holmesina and has more in common with $P$. typum, since $P$. humboldti presents well marked central figure (e.g. Cartelle and Bohórquez, 1984; Scillato-Yané et al., 2005; Góis et al., 2012). However, the characteristics are insufficient for determining at specific level. Pampatherium occurs in Minas Gerais, Rio Grande do Sul, Santa Catarina, Ceará, Maranhão, Bahia and Mato Grosso states (Góis et al., 2012).

Family Glyptodontidae Gray, 1869

Genus Glyptotherium Osborn, 1903

Glyptotherium sp. (Fig. 6Q-V)

Material: MCT4009-M, MCT4011-M, lateral buckler osteoderms; MCT4010-M, MCT4012-M, MCT4013-M, buckler osteoderms; MCT4007-M, middle-distal portion of left femur.

Comments: The material was determined as Glyptotherium based in the following characters. The osteoderms are hexagonal to sub-rectangular with an octagonal to round central figure surrounded by six to eight irregularly shaped peripheral figures subdivided by shallow radial 
sulci. A narrow shallow central sulcus separates the central figure from peripherals, which in its turn are all divided by radial sulci. Seven to eight foramina occur at the intersections of radial sulci with main sulcus. The external surface is rugose, and the central figure has a gentle depression. The central sulcus is deeper, with seven broad foramina. The femur has the third trochanter latero-distally expanded with rectangular shape. The intercondylar fossa is also very evident, wider anteriorlly and deeper caudally. The supratrochlear fossa is shallow and rounded shaped. The femur differs from Hoplophorus and Glyptodon by the sharper angle formed by the extremity of the third trochanter (e.g. Winge, 1915; Porpino et al., 2010). According to Oliveira et al. (2010), which redefined Glyptodontidae material of Brazilian Intertropical Region, Glyptotherium is characterized by thick plates with rugose surface, shallow crests and eight to nine peripheral figures, being the only Glyptodontidae of that region. Glyptodon, in its turn, would have fewer figures, deeper sulci and smoother surface. However, other later occurrences were reported as Glyptodon in Intertropical Region (Dantas et al., 2013a, 2013b), showing that both taxa may have coexisted. Indeed, the number of peripheral figures and foramina is variable with some overlap between the taxa (Dantas et al., 2013a; Zurita et al., 2012; Luna et al., 2018). The sulci are also less developed in the osteoderms of Glyptotherium (Zurita et al., 2012). Glyptotherium occurs in Tocantins, Rio Grande do Norte, Paraíba and Pernambuco (Dantas et al., 2013a; Luna et al., 2018).

Order Cetartiodactyla Montgelard et al., 1997

Family Camelidae Gray, 1821

Genus Palaeolama Palaeolama Gervais, 1867

Palaeolama major Liais, 1972 (Fig. 7A-K)

Material: MCT4060-M, left M2; MCT4057-M, right M2; MCT4059M, right M3; MCT4056-M, left M3; MCT4058-M, left m2; MCT4055-M, right m2; MCT4053-M, left m3; MCT4050-M, cervical vertebra; MCT4062-M, thoracic vertebra; MCT4051-M, MCT4049-M, MCT4066M, lumbar vertebrae; MCT4048-M, incomplete right humerus; MCT4293-M, MCT4052-M, left radio-ulna; MCT4044-M, MCT4046-M, right radius-ulna; MCT4289-M, left metacarpal; MCT4290-M, incomplete left metacarpal; MCT4063-M, MCT4037-M, proximal portion of incomplete right metacarpal; MCT4291-M, incomplete right metacarpal; MCT4294-M, right femur; MCT4065-M, MCT4197-M, left femur; MCT4047-M, incomplete right tibia; MCT4064-M, left astragalus; MCT4054-M, right calcaneus.

Comments: The teeth are selenodonts with mesio-distal length greater than lingual-labial width and V-shaped lingual lophs. M2 present deep and elongated talonid and trigonid fossae; labial styles are well marked and the mesostyle extends to the neck of the tooth, with deep mesial groove; parastyle is short and low. M3 has the same characteristics of M2, but in greater proportions; talonid and trigonid fossae are larger and more open, with almost triangular shape; near the neck of the tooth, on the lingual side of mesial lobe it is possible to observe a small enamel fold. The $\mathrm{m} 2$ have labial lophids with similar size; lingual stilide are well marked and extended to the neck of the tooth; metastilide is the highest and the distal fossa is deep and long; parastyle and the protostyle are developed forming a fold at mesial side; talonid and trigonid fossae are mesio-distally elongated, in the shape of a half-moon. The $\mathrm{m} 3$ is similar to $\mathrm{m} 2$ but more mesio-distally elongated; a third distal lobe formed by hypoconulide is also present, smaller than the other two. All teeth have little occlusal wear. The humerus distal portion has semi-cylindrical condyle divided by a well-marked groove, with the medial portion more distally extended and more rounded; the olecranon fossa is deep and delimited by two crests, forming an inverted "V". The radius-ulna is long and robust, with convex diaphysis in the anterior region and flattened in the posterior face; the olecranon is long and latero-medially flattened, with its axis aligned to the anconeal and pseudocoronoid processes. Femur with a long diaphysis and proximal portion antero-posterior flattened, the smaller trochanter is conical and elongated, and the femoral head is higher than the greater trochanter. Tibia with long diaphysis, with triangular section in the proximal portion to rectangular in the distal portion; the distal end has two deep, parallel oval cavities. The morphology matches with Palaeolama major (e.g. Cartelle, 1994; Scherer, 2005, 2009). The molars have diagnostic features such as V-shaped lingual lophs and lophids, well developed labial styles and lingual stylids, enamel fold on the lingual side of superior molar and of labial low molar and reduced parastyle and protostyle (Scherer, 2009). It differs from Lama, which has slightly developed labial and lingual styles, absence of enamel fold, developed protostyle and parastyle and U-shaped lophius and lophids, characteristic also common in Hemiauchenia (Cartelle, 1994; Scherer, 2005, 2009). Except for m3 (MCT4053-M), all other molars of $P$. major were found at the same point in the Gruna das Três Cobras, suggesting that the material belongs to the same individual. This species occurs in Rio Grande do Sul, Mato Grosso do Sul, Minas Gerais, Tocantins, Bahia, Maranhão, Ceará, Rio Grande do Norte, Paraíba, Sergipe and Pernambuco (Scherer, 2005, 2009; Scheffler et al., 2010; Buchmann et al., 2017).

Family Cervidae Gray, 1821

Cervidae indet. (Fig. 7L-N)

Material: MCT4288-M, incomplete metacarpal; MCT4039-M, MCT4292-M, incomplete left tibia; MCT4040-M, incomplete left metatarsal.

Comments: The material can be determined as Cervidae based in the following characters. Metapodials III and IV fused, only separated at the distal end, cannon shaped and antero-posteriorly flattened towards the distal end; a large longitudinal depression follows almost all diaphysis of the bone in the palmar face, beginning in the distal middle quarter of the bone and extending to the proximal end. The tibia is long with rectangular section near the distal end and more triangular towards the proximal end; the distal face is rectangular and composed of two well-delimited concavities, divided by a small median protrusion. The identification was made comparing material from MCTer collection (not numbered, reference collection) and from Cisneros (2005), Guérin and Faure (2009) and Dantas (2012). Among the cervid genera found in the Brazilian Intertropical Region, Mazama is the one with the highest occurrence records (Guérin and Faure, 2009; Dantas, 2012; Valli, 2018), but due to the incomplete state of the material, it is not possible to estimate the total length of the bones and to compare them properly, so the determination was kept at family level. The family occurs in Pleistocene deposits from Minas Gerais, Bahia, Pernambuco, Tocantins, Rio Grande do Norte, Ceará, Piauí, Goiás, Mato Grosso do Sul and Espírito Santo (Scheffler et al., 2010; Dantas and Cozzuol, 2016; Buchmann et al., 2017; Valli, 2018; Rotti et al., 2018).

Family Tayassuidae Palmer, 1897

Genus Tayassu Fischer, 1814

Tayassu pecari Link, 1795 (Fig. 70 and P)

Material: MCT4295-M, right dentary with pm3, p4, m1 and m2; MCT4072-M, right dentary with pm2, pm3, pm4, m1 and m2; MCT4071-M, MCT4073-M, right humerus; MCT4070-M, right radiusulna.

Comments: The material can be determined as T. pecari based in the following characters. Dentary with bunodont premolars and molars. The pm2 is sub-triangular and has well-developed central cusp and smaller distal cusp. The pm3 is rectangular and the mesial half is higher. The pm4 is molariform, sub-quadrangular and its four main cusps are individualized, although paracone and protocone are divided by a very narrow line; small accessory cusps occur mainly between the mesial and distal side cusps. The $\mathrm{m} 1$ is similar to $\mathrm{pm} 4$, but larger and more rectangular. In $\mathrm{m} 2$, four cusps are located at each angle of the tooth, all well chamfering divided. The humerus is robust, with a large and high tuberosity and a curved and robust deltopectoral crest; the ectepicondyle has a distal projection and the anconeal fossa is opened in a foramen. The radius-ulna has convex diaphysis on the anterior face and nearly flat on the posterior face; the distal end has four concave fossae for carpal bones. The material is very similar to those in MCTer collection (not numbered, reference collection), including the wear 

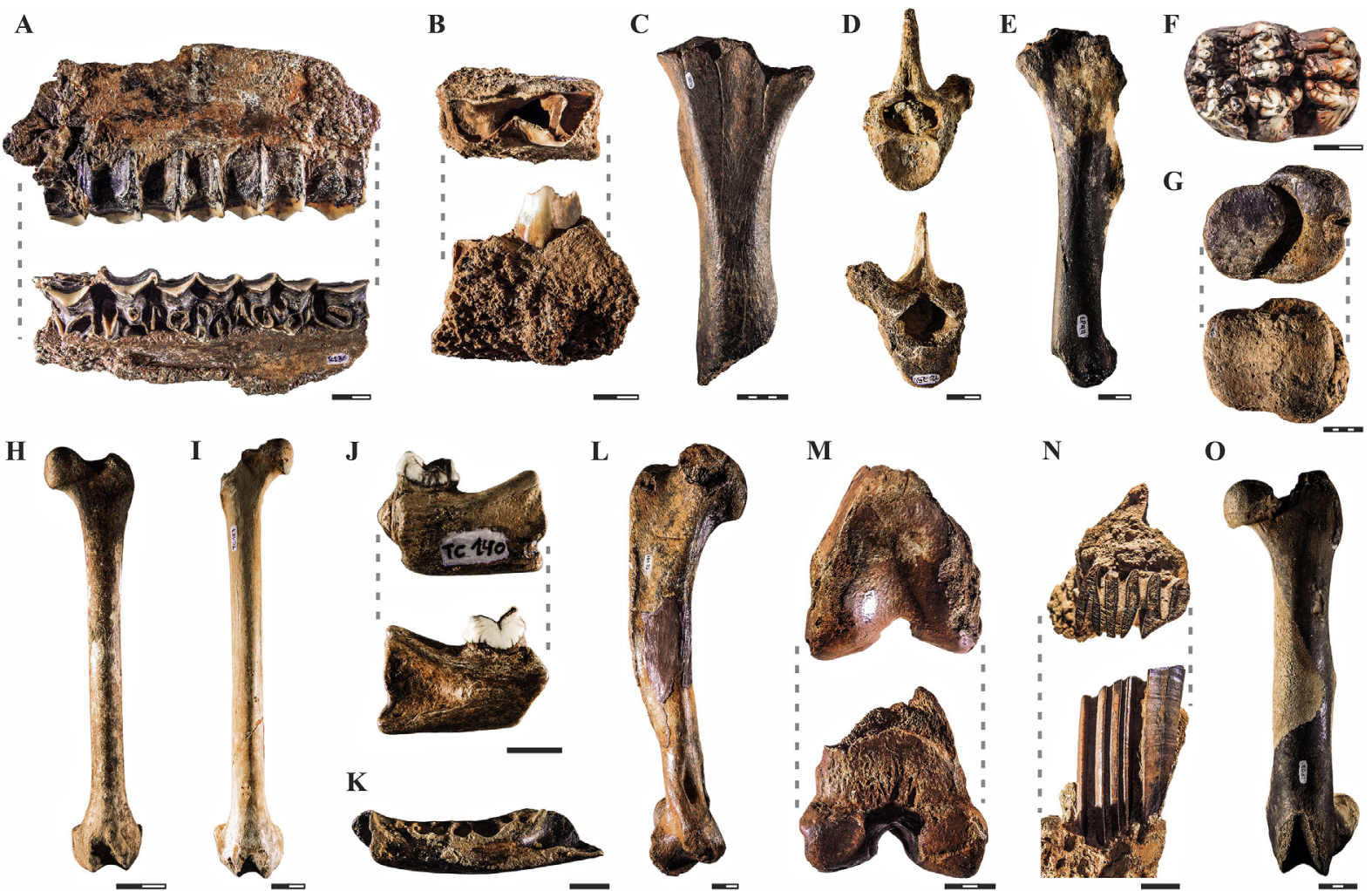

$\mathbf{L}$

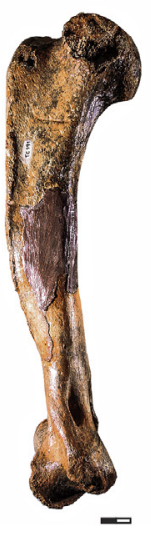

$\mathbf{M}$

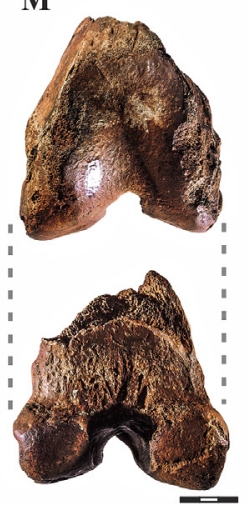

$\mathbf{N}$

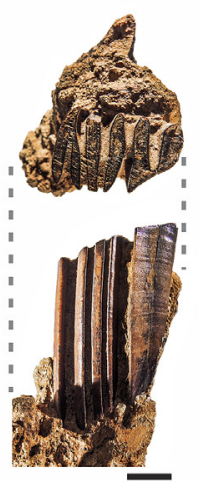

$\mathbf{O}$

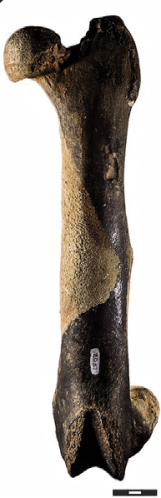

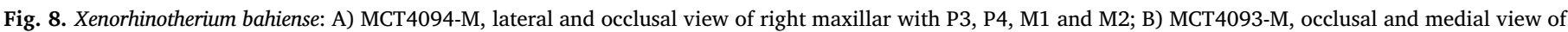

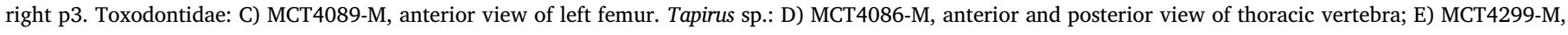

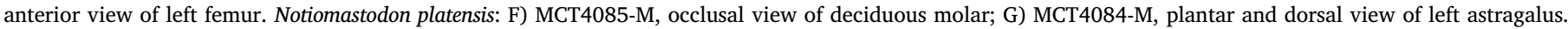

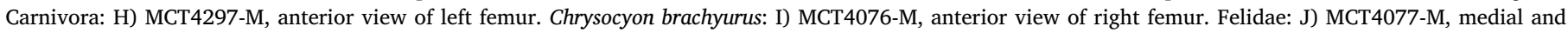

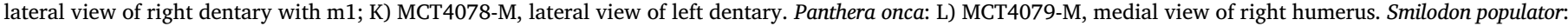

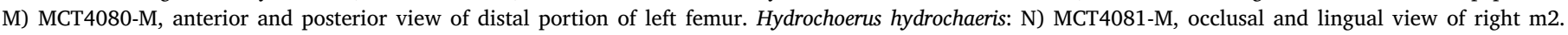
Neochoerus sp.: O) MCT4298-M, anterior view of left femur. Scale in centimeters.

degree, and the postcranial material also has dimensions compatible with T. pecari (e.g. Oliveira et al., 2010; Dantas et al., 2013b; Gasparini and Ferrero, 2010; Gasparini et al., 2009, 2013; 2014), especially well developed mesial cingulum and molariform premolar, different from Tayassu tajacu which, besides presenting smaller dimensions, does not present accessory cusps. This species occurs in Pleistocene deposits from Minas Gerais, Bahia, Rio Grande do Sul and Tocantins (Cartelle, 1999; Oliveira and Kerber, 2009; Buchmann et al., 2017).

Order Litopterna Ameghino, 1889

Family Macraucheniidae Gervais, 1855

Genus Xenorhinotherium Cartelle and Lessa, 1988.

Xenorhinotherium bahiense Cartelle and Lessa (1988) (Fig. 8A and B)

Material: MCT4092-M, left I1; MCT4091-M, right P1; MCT4090-M, right M3; MCT4094-M, right maxilar fragment with P3, P4, M1 and M2; MCT4093-M, dentary fragment with right $\mathrm{p} 3$.

Comments: The incisor (MCT4092-M) is spatulated, arched, with a cutting crown, directed towards the lingual face and longitudinally recurved. The P1 (MCT4090-M) has high paracone while the two other cusps, protocone and hypocone, are rudimental and low. The specimen MCT4094-M, P3, smaller tooth of the series, has subtriangular format and mesial cingulum, which delimits the mesio-lingual fossa and is connected to the protocone by a large crest; the hypocone, distal cusp to the median fossa, is poorly developed; the metastyle is less developed than the other labial styles, however it is well marked on the labial face. P4 is molariform, with sub-quadrangular shape, and differs from molars by its smaller size; the mesostyle and the parastyle are more developed, while the metastyle is reduced; the paracone is little higher than the metacone. The molars, M1 and M2, are rectangular with well-developed mesostyle and parastyle; the metastyle is reduced when compared to the other styles; paracone and metacone have almost the same height and arrangement, intermediated by a deep median fossa of nearly ellipsoid shape. The p3, specimen MCT4093-M, is mesio-distally elongated and has a high protocone and conical and smaller metacone, arranged more obliquely in relation to the anterior crest. The species is identified mostly by the rectangular shape of superior molars, mesostyle development, elongated lower molar with internal lophids. The other two species of Macraucheniidae family of Pleistocene are Macrauchenia patachonica and Macraucheniopsis ensenadensis, however only the first one is found in Brazil, more specifically in southern Brazil (e.g. Scherer et al., 2009). M. patachonica and M. ensenadensis have features such as less rectangular superior molars, less developed mesostyles and absence of entolophyd in $\mathrm{p} 4$, which distinguish it from $X$. bahiense. Furthermore, teeth measurements coincide with those given by Lessa (1992), indicating a medium-sized individual. According to Lessa (1992), incisors wear causes obliquity in the most distal part of the occlusal face of the tooth and as wear occurs in the first superior premolars, a distal fossa appears followed by a mesial one, which will disappear over time. As in P1 two fossae are still present, as well as only three fossae in P4 and one lanceolate lingual border in some molars medial fossae, it probable means that it is an adult not so old individual. Considering that it was all collected in the same place, it is possible that all material belongs to the same individual. Having this taxon in that region corroborates the proposal of Xenorhinotherium bahiense as the only Macraucheniidae of the Brazilian Intertropical Region (Cartelle and Lessa, 1988). This species occurs in Goiás, Minas Gerais, Bahia, Alagoas, Pernambuco, Paraíba, Rio Grande do Norte and Piauí (Cartelle, 1999; Dantas and Cozzuol, 2016).

Order Notoungulata Roth, 1903 
Family Toxodontidae Gervais, 1847

Toxodontidae indet. (Fig. 8C)

Material: MCT4089-M, incomplete left femur.

Comments: Robust, antero-posteriorlly flattened femur, lacking the proximal and distal portions. The anterior face is flat to slightly concave. On the posterior-medial face, near the proximal end and right distally to the caput neck, the lesser trochanter forms a small longitudinal crest. According to a review by Dantas (2012) of Pleistocene megafauna in the Brazilian Intertropical Region, two genera of Toxodontidae are found: Toxodon and Trigodonops, but another species was described by Guérin and Faure (2013), Piauhytherium capivarae. The femur presents the typical morphology and size of Toxodon platensis (e.g. Dantas, 2012; Mendonça, 2012), the most representative of those genera, but their femurs are anatomically similar, differing more in morphometric proportions (e.g. Guérin and Faure, 2013). Since it is a single and incomplete specimen, this comparison is not possible and the determination was maintained at family level. The family occurs in Pleistocene deposits from Rondônia, Minas Gerais, Bahia, Sergipe, Alagoas, Pernambuco, Piauí, Rio Grande do Norte, Ceará, Goiás, Mato Grosso do Sul, Rio Grande do Sul, Paraná, São Paulo and Rio de Janeiro (Cartelle, 1999; Sedor et al., 2004; Holanda, 2007; Oliveira and Kerber, 2009; Scheffler et al., 2010; Ghilardi et al., 2011; Guérin and Faure, 2013; Dantas and Cozzuol, 2016).

Order Perissodactyla Owen, 1848

Family Tapiridae Burnett, 1830

Genus Tapirus Brünnich, 1772

Tapirus sp. (Fig. 8D and E)

Material: MCT4086-M, thoracic vertebra; MCT4299-M, incomplete left femur.

Comments: Vertebra with long and thin neural apophysis and much reduced zygapophyses. The femur is slightly sigmoid in shape, with a wide neck at the caput base and a flattened third trochanter laterally extended in the diaphysis proximal half. The material was recognized by comparison with specimens from MCN and MCTer collections (not numbered, reference collections). Despite the current wide distribution of this genus, occurrences in Brazilian Pleistocene deposits are rare, with records in Minas Gerais, Bahia, Tocantins and Paraná (Cartelle, 1999; Sedor et al., 2004; Gasparini et al., 2015). Three species, T. terrestris, T. cristatellus, and T. rondoniensis are known in the Brazilian Pleistocene (e.g. Cartelle, 1999; Holanda, 2007; Holanda et al., 2011), but the material studied here is incomplete and not diagnostic at a specific level, since those taxa are based mainly in cranial and dental characters. Tapirus occurs in Pleistocene deposits from Acre, Rondônia, Bahia, Pernambuco, Rio Grande do Norte, Minas Gerais, São Paulo, Rio Grande do Sul, Paraná, Mato Grosso and Mato Grosso do Sul (Holanda, 2007).

Order Proboscidea Illiger, 1811

Family Gomphotheriidae Hay, 1922

Genus Notiomastodon Cabrera, 1929

Notiomastodon platensis (Ameghino, 1888) (Fig. 8F and G)

Material: MCT4085-M, right DP3; MCT4084-M, left astragalus.

Comments: Astragalus and molar are similar to the Notiomastodon material from MCTer collection (MCT73-M, MCT74-M, MCT75-M, MCT78-M, MCT87-M, МСT93-M, МСТ147-M), with typical Gomphoteriidae morphology such as follow. Astragalus has a quadrangular aspect and is dorsal-palmar flattened; the articular facet for tibia is slightly convex; the medial trochlea is more elongated and convex than its opposite, without trochlear groove; the articular surface for the calcaneus is divided into two facets by sulcus tali, the sustentacular facet is flat and larger than the ectal facet. The molar is bunolophodont and trilophodont with several accessory conules and little wear in the highest cusps; possibly the second or third deciduous molar. In recent reviews, Mothé et al. (2012, 2017) concluded that Brazilian occurrences of Stegomastodon correspond to Notiomastodon platensis. Although the diagnosis is based primarily on dental characters, the astragalus can be identified by comparison with the collection material and follow the same identification of the molar. The species occurs in Acre, Alagoas, Bahia, Ceará, Goiás, Mato Grosso, Mato Grosso do Sul, Minas Gerais, Pará, Paraíba, Paraná, Pernambuco, Piauí, Rio Grande do Norte, Rio Grande do Sul, Rio de Janeiro, Rondônia, Santa Catarina, São Paulo and Sergipe (Sedor et al., 2004; Scheffler et al., 2010; Ghilardi et al., 2011; Mothé et al., 2012, 2017).

Order Carnivora Bowdich, 1821

Carnivora indet. (Fig. 8H)

Material: MCT4297-M, left femur.

Comments: The femur exhibits a cylindrical and long diaphysis without projections, the head and greater trochanter of the same length and the lesser trochanter in medial-posterior position, characteristics common to Carnivorous, particularly Canidae and Felidae (e.g. PaulaCouto, 1979). It differs from Cetartiodactyla, whose diaphysis is more robust with a wider patellar facet and the greater trochanter is longer than the head (e.g. Scherer, 2005; Valli, 2018). In Primates, the patellar facet is shorter and distal, and the lesser trochanter occupies a more medial position than in the studied material (e.g. Paula-Couto, 1979). The absence of a third trochanter and the position of the lesser trochanter allow to distinguish it from other potential occurrences. Among the Carnivorous, there are a large number of taxa with size and morphology close to the studied material (e.g. Paula-Couto, 1979; Reis et al., 2006), which prevents identification at the genus level.

Family Canidae Fischer, 1817

Genus Chrysocyon Smith, 1839

Chrysocyon brachyurus (Illiger, 1815) (Fig. 8I)

Material: MCT4076-M, right femur.

Comments: Femur with basically the same characteristics of the previous material but with an unusually long diaphysis. Such dimensions and degree of elongation are achieved only by the maned wolf Chrysocyon brachyurus, the largest extant canid in South America, particularly slender and graceful. Other carnivores, extant and fossil, of comparable size include the canid Protocyon troglodytes, felids such as Smilodon populator, Panthera onca and Puma concolor and bears such as Arctotherium wingei (e.g. Paula Couto, 1979; Prevosti and Vizcaíno, 2006; Reis et al., 2006; Soibelzon and Tartarini, 2009), but their femurs are proportionately more robust and thick. The studied specimen presents morphology and size compatible with the material of Siqueira et al. (2017), who described the posterior locomotor appendage of $C$. brachyurus extensively. The taxon has previously been recorded in Pleistocene faunas in Minas Gerais (Cartelle, 1999).

Family Felidae Fischer, 1817

Felidae indet (Fig. 8J and K)

Material: MCT4077-M, right dentary fragment with m1; MCT4078$\mathrm{M}$, incomplete left dentary.

Comments: The material can be determined as felidae based on the morphology of $\mathrm{m} 1$, morphologically simple, with two sharp cusps forming divergent lamina. The dentary is narrow with a deep masseteric fossa and three nutritious foramina in the anterior lateral face. The left dentary does not have preserved teeth, but has canine alveoli, two premolars and a molar. The alveolus for $\mathrm{m} 1$ has large anterior root and reduced second root. The simplified form of $\mathrm{m} 1$ is typically of Felidae carnassial teeth (Paula Couto, 1979). The dental formula and alveoli shape also coincides with Felidae (Reis et al., 2006). The material was compared to MCTer specimens (not numbered, reference collection). Among South American cats, the dimensions are compatible with Leopardus pardalis or young individuals of Puma concolor, but no significant differences in molar or dentary morphology were observed to allow identification. Although they come from the same point and have similar dimensions, it is not possible to conclude they are from the same individual.

Panthera onca (Linnaeus, 1758) (Fig. 8L)

Material: MCT4079-M, right humerus.

Comments: The humerus is robust in the proximal portion, with strong deltopectoral crest. The caput is large in proportion to the bone and the great tuberosity is presented as a crest. At the distal end, a 
A

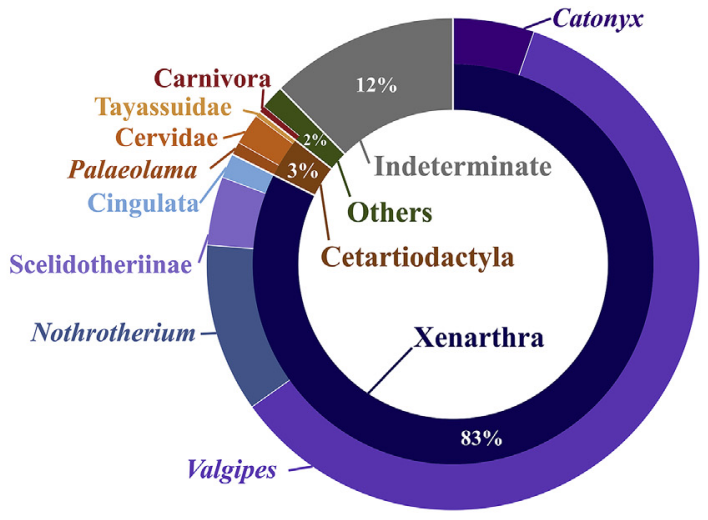

B

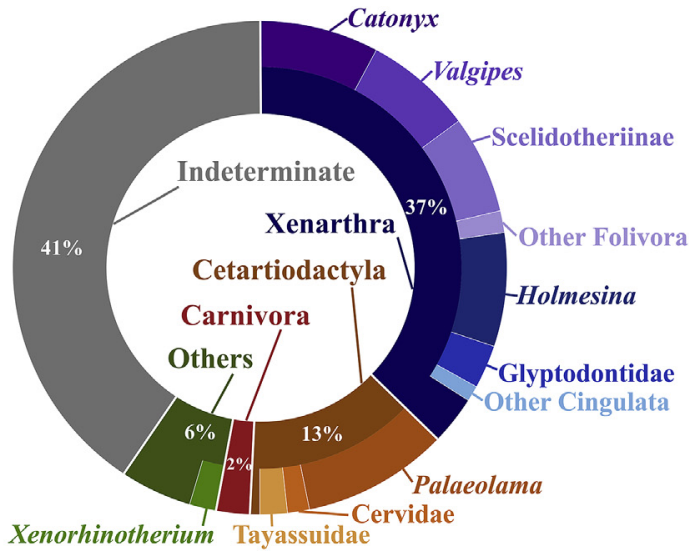

Fig. 9. Taxonomic representativity of fossil association, based on the determination of taxa in less inclusive levels. A) Lapa dos Peixes; B) Gruna das Três Cobras.

strong ectepicondylus supinator crest, while entepicondylus has supracondyloid foramen. The anconeal fossa is not perforated. Such features are typical of large felids (e.g. Diedrich, 2007), and the material is similar to Panthera onca observed in MCTer (not numbered, reference collection). Measures are too large for Puma concolor, and small for Panthera atrox or Smilodon (Reis et al., 2006; Meachen-Samuels and Van Valkenburgh, 2010), which also have more robust and thicker humerus. This species occurs in Pleistocene deposits from Minas Gerais, Bahia, Piauí, Tocantins and São Paulo (Cartelle, 1999; Ghilardi et al., 2011; Rodrigues et al., 2014).

Smilodon populator Lund, 1842 (Fig. 8M)

Material: MCT4080-M, distal portion of left femur.

Comments: The material presents the characteristics common to Carnivora, as previously described, as two strong and rounded condyles sharing the same articular surface with the patellar facet, which is high and slightly elongated in the proximal-distal direction. The suprapatellar fossa is not very visible. The entocondyle is larger and wider than the ectocondyle, both forming an open angle with the articular surface, as in S. populator (Castro and Langer, 2008). The intercondylar fossa is deep and widens in the anteroposterior direction. The posterior face houses the rugose area for the gastrocnemius muscle (Castro and Langer, 2008). The morphology and dimensions coincide with specimens from the MCN collection (MCL-7161 to 7163) and literature (e.g. Cartelle and Abuhid, 1989; Castro and Langer, 2008; Meachen-Samuels and Van Valkenburgh, 2010). Although incomplete, the material has characteristics to be concluded as Smilodon populator. This species occurs in São Paulo, Minas Gerais, Bahia, Paraíba, Pernambuco, Sergipe, Rio Grande do Norte, Ceará, Piauí, Goiás and Mato Grosso do Sul (Cartelle, 1999; Scheffler et al., 2010; Ghilardi et al., 2011; Dantas and Cozzuol, 2016).

Order Rodentia Bowdich, 1821

Family Hydrochoeridae (Gray, 1825)

Genus Hydrochoerus Brisson, 1762

Hydrochoerus hydrochaeris (Linnaeus, 1766) (Fig. 8N)

Material: MCT4081-M, right m2.

Comments: The molar has typical morphology of Hydrochoerus hydrochaeris (e.g. Paula Couto, 1979; Mones and Ojasti, 1986; Kerber and Ribeiro, 2011), which consist in hypsodont molar composed of six transverse laminae, the first two labially connected and the last two lingually, Y-shaped. The occlusal surface is flat due to wear. The material differs from Neochoerus both by size and number of lophs. $H$. hydrochaeris is the largest living rodent, with widespread distribution in South America. This species occurs in Pleistocene deposits from Minas Gerais, Bahia, Pará, Santa Catarina, Rio Grande do Norte, Mato Grosso do Sul and Rio Grande do Sul (Cartelle, 1999; Oliveira and Kerber, 2009; Kerber, 2017).

Genus Neochoerus Hay, 1926

Neochoerus sp. (Fig. 80)
Material: MCT4298-M, left femur; MCT4082-M, incomplete left femur; MCT4083-M, incomplete right femur.

Comments: Thick and slightly curved femur. The greater trochanter is taller than the caput, which is well rounded with a narrow neck. The lesser trochanter is well pronounced and posteromedially oriented. The trochanteric fossa is quite deep. The third trochanter is protruding and elongated, almost forming a crest in the middle lateral portion of the bone. The distal portion has two condyles of similar size separated by a large intercondyloid fossa. The patellar facet is quite high, elongated and narrow. The material is morphologically similar to Hydrochoerus (Araújo et al., 2013), but its large dimensions are compatible with Neochoerus as described by Carranza-Castaneda and Miller (1988). The genus Neochoerus presents several species described in America (e.g. Carranza-Castaneda and Miller, 1988; Mones, 1991) but specific determination is based in cranial and dental characters and is not possible with the analyzed material. Neochoerus occurs in Minas Gerais, Bahia and Rondônia (Kerber, 2017).

\subsection{Taphonomical aspects}

\subsubsection{Lapa dos peixes}

The diversity of Lapa dos Peixes were 13 taxa. Among the total bones observed, $81 \%$ are ground sloths, $60 \%$ identified as Valgipes bucklandi, $11 \%$ as Nothrotherium maquinense, $5 \%$ as Catonyx cuvieri and $5 \%$ as undetermined sloths. Cingulata corresponds to $2 \%$. The remaining fossils add up to $5 \%$, and $12 \%$ could not be determined (Fig. 9A). The minimum number of individuals (MNI) was estimated by observing repetition of the most abundant bones while the number of identified specimens (NISP) was calculated taking into account only taxonomically identified material (Table 1), following Araújo-Júnior et al. (2012). Thus, it was verified at least seven individuals of $V$. bucklandi, three individuals of $C$. cuvieri, two individuals of $N$. maquinense and one individual of an undetermined sloth. The other taxa were recovered isolated in the cave and probably grouped eight individuals, including three Cetartiodactyla, two Cingulata, one Rodentia, one Carnivora and one Perissodactyla. The most abundant elements identified correspond to ribs, vertebrae, long bones and autopodials. There are few elements anatomically undetermined. About 38\% of the material fit in group 1 of Voorhies and 57\% in group 2 (Fig. 10). Most fossils occur without breaks or with few pre-fossilizations breaks, prevailing those with no signs of weathering, with little or no abrasion.

The non-parametric correlation between FTI and bone representativity for the associations of Lapa dos Peixes resulted in a value of -0.13 ( $\mathrm{p}=0.59$ ). According to Araújo-Júnior et al. (2012), these values would be closer to the neutrality, indicating homogeneity in relation to the quantity of less and more transportable elements, practically without hydraulic selection. Some bias in this result is expected due to the current erosive processes involved in the exhumation of the 
Table 1

Relation between taxa, bone representativity, number of identified specimens (NISP) and minimum number of individuals (MNI) in each of the studied caves.

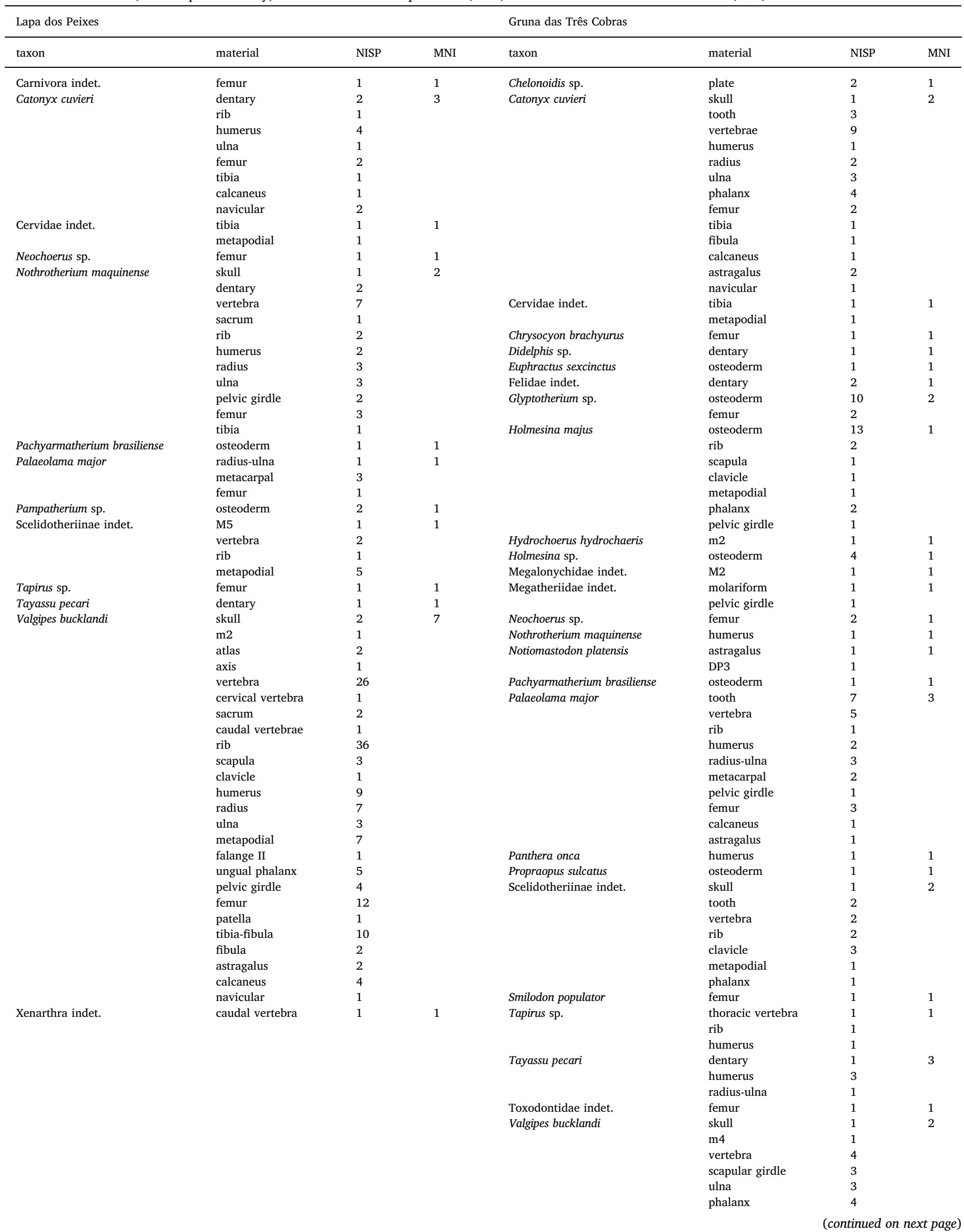


Table 1 (continued)

\begin{tabular}{|c|c|c|c|c|c|c|c|}
\hline Lapa dos Peixes & & & & Gruna das Três Cobras & & & \\
\hline \multirow[t]{13}{*}{ taxon } & material & NISP & MNI & taxon & material & NISP & MNI \\
\hline & & & & & pelvic girdle & 2 & \\
\hline & & & & & metatarsal & 1 & \\
\hline & & & & & osteoderm & 1 & \\
\hline & & & & Xenarthra indet. & caudal vertebra & 3 & 1 \\
\hline & & & & & scapula & 1 & \\
\hline & & & & & humerus & 1 & \\
\hline & & & & & metapodial & 2 & \\
\hline & & & & & phalanx & 4 & \\
\hline & & & & & astragalus & 1 & \\
\hline & & & & Xenorhinotherium bahiensis & maxilar & 1 & 1 \\
\hline & & & & & dentary with $\mathrm{p} 3$ & 1 & \\
\hline & & & & & tooth & 3 & \\
\hline
\end{tabular}

bones, which can cause the loss of fragile elements, and because the analysis is based only on large animals, in this case mainly sloths. The result is similar to those indicated by the Voorhies groups.

In Lapa dos Peixes, irregular perpendicular and spiral breaks were more abundant. The amount and intensity of each breakage are shown in Fig. 11A. Post-fossilization breaks were identified in 53\% of the bones (from 236 specimens), while $34 \%$ presented pre-fossilization breaks (Fig. 11B), suggesting little influence of factors which could produce bone breakage (transport, trampling, scavenging) prior to fossilization for most specimens (Shipman, 1981; Lyman, 1994). About $90 \%$ of the bones have weathering degree ranging from 0 to 1 , evidencing little or no subaerial exposure prior to burial (Behrensmeyer, 1978, Fig. 11C).

The mode A represents $84 \%$ of the bones in Lapa dos Peixes, prevailing partial skeletons with the three groups of Voorhies, little or no weathering and abrasion and rare pre-fossilization breaks. It was recorded Catonyx cuvieri, Valgipes bucklandi and Nothrotherium maquinense. These individuals were buried articulated or only locally disarticulated, without transportation, with short time of subaerial exposure and recently exhumed. Mode $\mathrm{B}$ includes transported and isolated bones with usually spiral or columnar pre-fossilization breaks, predominance of group 2 of Voorhies and higher degree of weathering and abrasion. Only $9 \%$ of the material is in this category, with Tayassuidae, Scelidotheriinae, Cingulata and Carnivora registered. These bones would have been transported into the cave or remobilized, although they do not show evidence of exhumation and redeposition. In addition, mode $C$ includes three specimens with punctures as evidence of scavenging and mode D includes another 14 undetermined bones due to high degree of post-fossilization breakage.
The main fossil association of Lapa dos Peixes, containing $N . \mathrm{ma}^{-}$ quinense and $V$. bucklandi, were recovered from two distinct sites in the cave (Fig. 12), sectors LPIII and LPIV respectively.

The concentration and predominance of $V$. bucklandi adults in the sector LPIV, most of them originally articulated (mode A), could be an indication of selective, possibly accidental death. The fossils were recently disarticulated and broken due to erosive processes in the cave deposits, but the low degree of pre-fossilization breakage suggests lack of transportation and rapid burial (Behrensmeyer, 1978; Shipman, 1981; Lyman, 1994). These upstream segment of Lapa dos Peixes has a main fluvial conduit, which is now inactive. The main conduit is sided by a network of secondary galleries and chambers positioned at slightly higher levels, where the mode A fossils were found in the highest part. Based on the arrangement and morphological aspects of these galleries, this sector had been subject to periodic flooding in the past, just as they do today in still active parts downstream in the cave, so that the higher parts could offer shelter in flood situations. So, the animal entrapment due to episodic and sudden elevations of the river level is one of the plausible hypothesis for the selective death. These animals could eventually visit the cave searching for nutritional supply, like mineral salt or just water, as many modern mammals do (Klaus et al., 1998), or even use the cave as a shelter. In karstic river systems, caves are potential natural traps and it is very common to experience drastic water level rises and total underground flooding, due to the rapid infiltration of rainfall without the corresponding outflow capacity (Palmer, 1991; Hubbe and Auler, 2012). But the hydric energy in the lateral overflow branches is considerable lower than in the main channel due their labyrinthine and confined character, so these can be places for sedimentary aggradation as well as places subject to reduced movement of
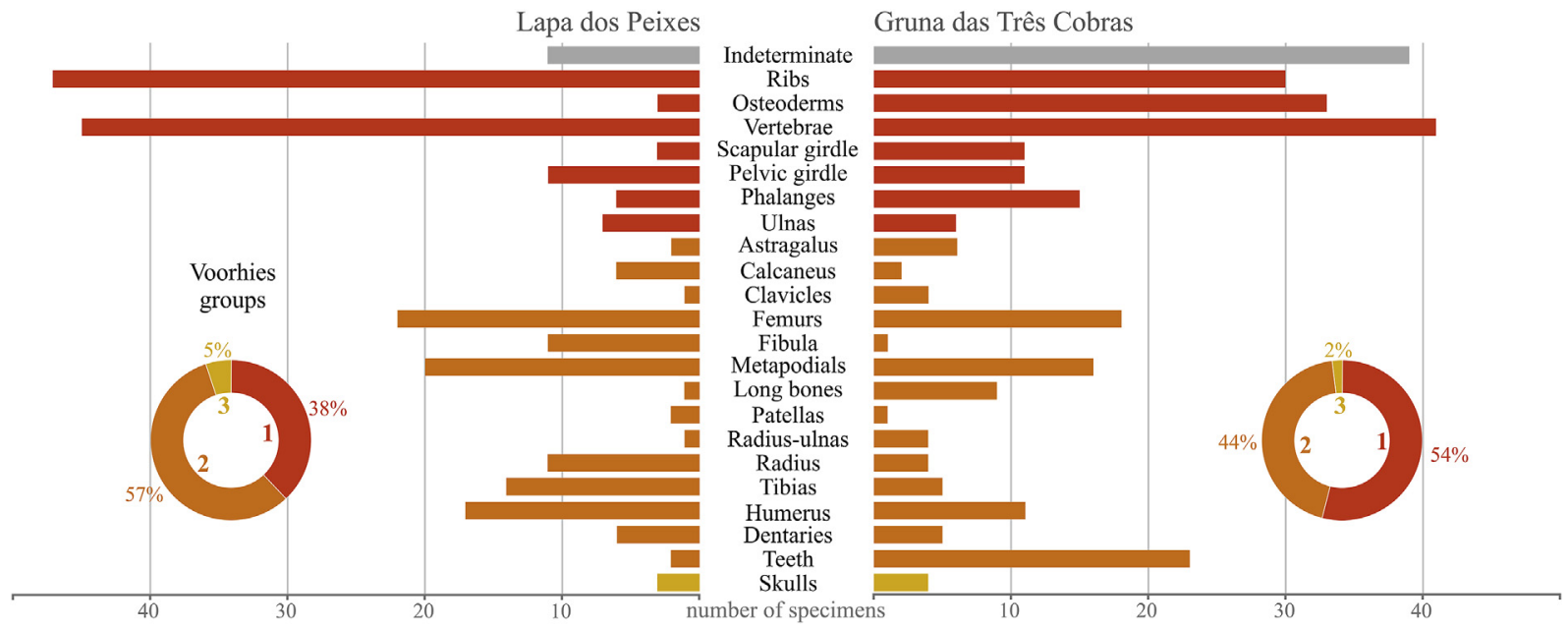

Fig. 10. Bone representativity of fossil association and proportion of Voorhies groups of hydraulic selection. 
A

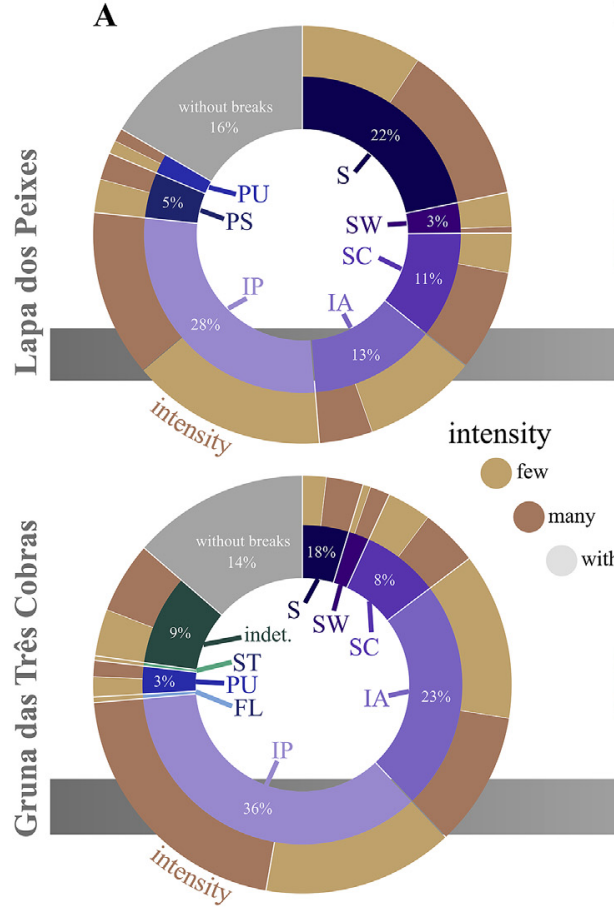

B

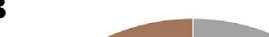

C 


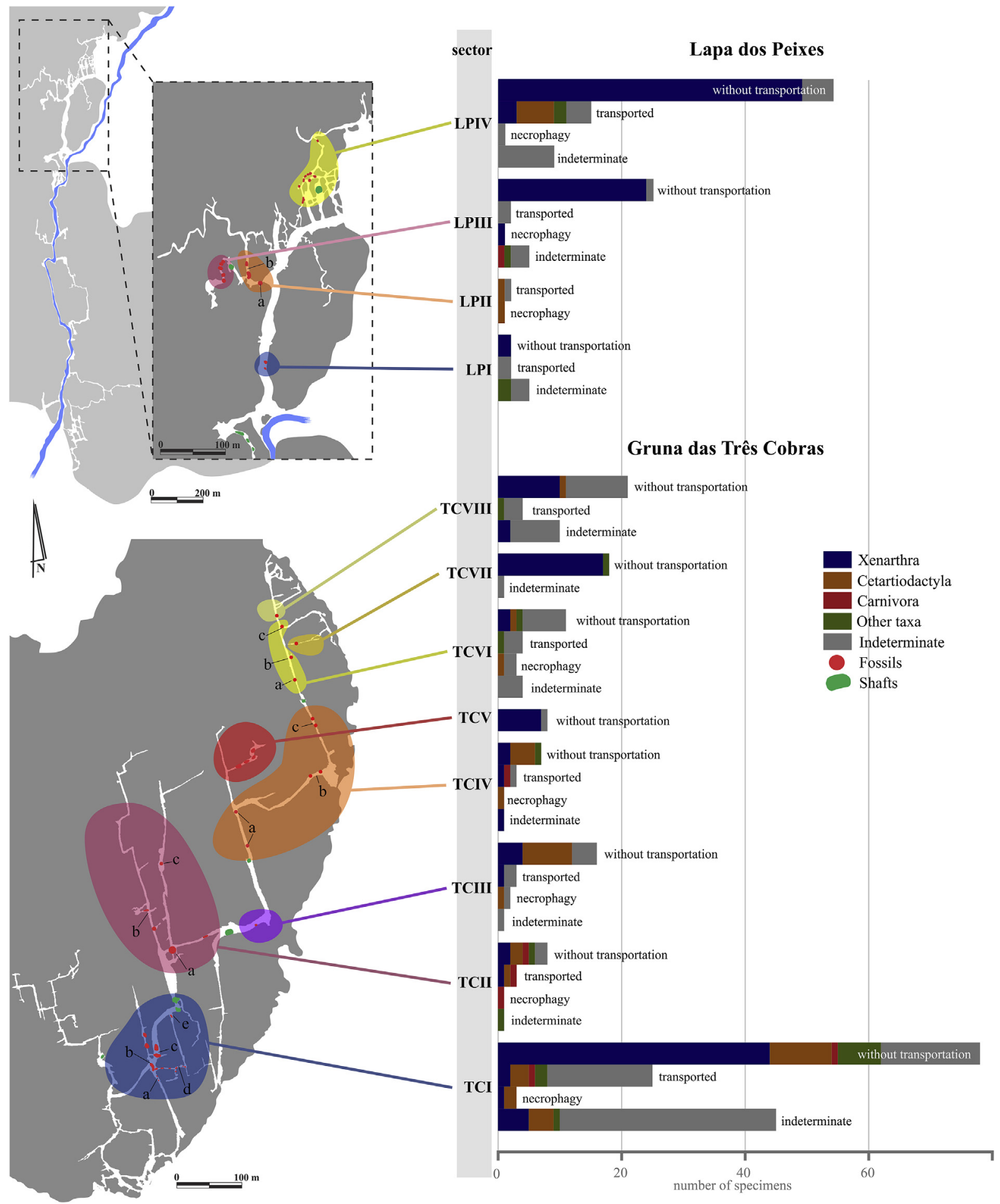

Fig. 12. Fossils distribution in the studied caves, with number of specimens per taxon in each taphonomic mode in the different sectors (maps based on Bittencourt and Rodet, 2002, and Sausse, 2013).

1978). Mode B is $15 \%$ of the material and includes isolated bones, with usually spiral or columnar pre-fossilization breaks, predominance of group 2 of Voorhies and greater degree of weathering and abrasion. It occurs mainly in Cetartiodactyla, Xenarthra and Carnivora. These elements are mainly small to medium-sized animals and therefore do not appear in FTI analysis. Mode C corresponds to only $4 \%$ of the bones, with evidence of necrophagy and represents the consumption of carcasses inside the cave by scavengers, probably Carnivora. The other $22 \%$, corresponding to mode $\mathrm{D}$, remain undetermined due to high degree of post-fossilization breakage.

The bones of TCI-c and TCI-d sectors, identified as C. cuvieri and V. bucklandi, do not present bone repetition and it is possible to infer that each association represents an individual which was preserved at least partially articulated, and only during the most recent pluvial erosion process was disarticulated and accumulated (Fig. 11). The same happens with Scelidotheriinae of TCV sector and with Holmesina majus of TCVII sector. The TCI sector had the highest amount of material, but it is also the most affected by erosion, with higher proportion of 
transported and undetermined material.

Thus, the ocurrences in Gruna das Três Cobras correspond to an association dominated by isolated individuals, without significant transport prior to fossilization and with time averaging. According to the criteria of Simms (1994), there would be a balance between the several biotic elements, with a prevalence of biotic autochthonous. The association could be classified as spatial-mixed, predominantly in situpreserved assemblage (Araújo-Júnior, 2016). The morphological pattern of the cave, with large number of fissures, entrances and shafts, and the spatial distribution of the fossils suggest that some groups were more likely to occupy the caves and their surroundings, while others were transported into the cavities by different factors (e.g. Hubbe and Auler, 2012). There are not signs of fluvial action related to deposition, and the input and preservation of the transported bones (mode B) seems to be more related to the gravitational injection of sediments.

\subsubsection{Regional aspects}

In both caves, there was a tendency for preservation of bones without significant pre-fossilization transport, with lower proportion of transported material (Fig. 12). The results here contrast with other similar studies, such as Santos et al. (2002), Vasconcelos et al. (2015), Maldonado et al. (2016) and Buchmann et al. (2017), who verified a higher proportion of transported fossils in deposits formed from gravity and water flows. Most fossils recorded in the present study are linked to different endogenous sedimentary deposits, with a few of them preserved in encrustation beds, which shows a time averaging. In drier periods, vegetation is less dense, and erosion is stronger on the surface, with greater input of sediments into the cavities in episodic events, resulting in significant endogenous deposits (Auler et al., 2003, 2009). During wetter periods, much of the sediment is retained on the surface by vegetation, and the greater water activity is responsible for carbonate precipitation involving preexisting sediments, forming layers and coverings with carbonate cementation. Erosion and sediment removal from caves are related to intermediate conditions prevailing in the current climate (Auler et al., 2003, 2009; Piló, 1988).

Pre- and post-fossilization breakages stand for at least two distinct phases of sedimentary history (e.g. Auler et al., 2003), an ancient one linked to deposition and the currently active erosive phase. The predominance of breaks in already mineralized bones and the presence of suspended stalagmitic caps with eroded sedimentary base indicate a time span between these phases (deposition-erosion) which was enough to allow partial mineralization of bioclasts.

The depositional phase includes occupation of cave environments by animals, with eventual imprisonment death, and input of animal remains by fluvial activity, gravitacional processes, and accidental fall or by scavengers' action. The deposition and consequent burial of bioclasts occurred at various moments of dry climate alternated to humid climate, with incorporation of bones, respectively in clastic and chemical deposits, resulting in temporal averaging as was observed. With burial, the bones would then be subject to diagenetic changes especially from percolation of solutions saturated in calcium carbonate which lead to calcite precipitation in the bone interstices and loss or replacement of the original constituents.

Cycles of sedimentary reworking may have occurred prior to the current vadose erosional phase, but the combined occurrence of modes A and B fossils with the three Voorhies groups preserved does not seem to support the existence of long distance transportation of fossils. In this case, exhumation and redeposition would act on both articulated and previously transported fossils, with strong hydraulic selection acting on bioclasts dispersion (e.g. Behrensmeyer et al., 1992; Shipman, 1981; Lyman, 1994) unlike what was observed. More recently, the deposits have undergone multiple cycles of low energy reworking, which would result in the mobilization of finer sediment but keeping the fossils near the original location. Thus, post-fossilization breakage would be more related to local remobilization of fossils during erosion and possibly to isolated events of reworking previous deposits without significant transport.

The pluvial erosion currently acting in these caves is a destructive phenomenon that compromises the fossils integrity in the long term and may result in their total destruction. On the other hand, such exposure was exactly what allowed the sampling of a significant amount of material in almost all sectors of these caves in a relatively short period of time, what would be impossible through controlled excavations (e.g. Vasconcelos et al., 2015). Thus, it was avoided the impacts of cave excavation which could compromise other studies in these environments, such as those involving the current biota (e.g. Bichuette and Rizzato, 2012). For paleontological studies, it should have annual or biennial monitoring in order to rescue exposed fossils after each rainy season, thus minimizing the loss of paleontological information.

Although absolute dating was not performed in this study due to lack of resources and the large amount of collected material, for these fossil associations the age was estimated ranging from Late Pleistocene to Early Holocene, which is indicated by other authors as the representative period of the fauna herein described (e.g. Hubbe et al., 2011; Maldonado et al., 2016; Buchmann et al., 2017). This age is compatible with scelidotheriines occurrences in caves in the Minas Gerais state (Piló and Neves, 2003; Hubbe et al., 2009, 2011), where ages between 13 and $9 \mathrm{kyr}$ were obtained. Similar palaeofaunas were recorded in Guanambi, a locality near Serra do Ramalho where natural tank deposits aged between 22 and $16 \mathrm{kyr}$ ago are related to dryer periods (Scherer et al., 2017). Geochronological studies in cave speleothems of the central region of Brazil have demonstrated the occurrence of several cycles of wetter and dryer periods, the most recent ones concentrated between 30 and $10 \mathrm{kyr}$ ago, which may coincide with the time interval studied (Auler et al., 2009; Stríkis et al., 2018).

These records of wetter and dryer periods in different caves, although indicating a general pattern, may suffer local and regional influences related to factors such as land elevation rates, microclimate, sedimentary availability (source area), deposition/erosion rate and others (e.g. Auler et al., 2009). Records of dryer periods may be abundant in contexts of stable cratonic areas, such as the San Francisco Craton, where the studied caves are inserted on. In these areas, the caves are influenced by sedimentation for longer periods of time than in tectonically active areas, covering on average at least three glacial-interglacial cycles, which can be considered the base factor to the broad sedimentary content in the caves studied, specially the clastic one (Auler et al., 2009; Stríkis et al., 2018). But other rulling factors such the watershed configuration and the evolving geomorphology should be also in the focus for better understanding the patterns of the local karst depositional systems.

The Serra do Ramalho region clearly had a rich biodiversity during the Pleistocene. The presence of groups that are ecologically diverse, with so different habits as browers, mixed-feeders, grazers and carnivores denotes a complex history, with several paleoecological and paleobiogeographic factors acting over time. With a rich paleofauna, a large number of caves and still with few studies, the Serra do Ramalho region shows great potential for paleoenvironmental and geochronological research and future studies in the region may contribute to the knowledge about the history of the Pleistocene in South America.

\section{Conclusion}

The diversity of the two caves at the Serra do Ramalho region is 29 taxa. The study was limited to naturally exposed material, which in itself tends to concentrate larger and denser elements. Despite this, all transported groups are represented, including small and light elements such as osteoderms. This study condition provided a large sampling of all two caves in a way that would be impossible with traditional excavation techniques.

The data suggest a taphocoenosis predominantly composed by complete elements, without significant transportation, but also by transported elements. The associations could be classified as spatial- 
mixed, predominantly in situ-preserved assemblages.

The faunistic composition of the studied caves, with great predominance of Xenarthra, is affected by this taphonomic bias, since these animals would have life habits related to cave environment thus having greater chances of preservation. In the LPIV sector, Lapa dos Peixes, there are signs of accidental death in the scelidotheriines group that could be related to entrapment in one or more river flooding events. This hypothesis requires more detailed morphogenetic and sedimentary examination on the cave compartments in order to verify the dynamics of rising and lowering of the water level related to the past flow conditions in this system.

Despite the great field effort expended in the Sanfranciscana Depression system, with dozens of caves having been studied, fossils were found expressively in only two caves, which shows the particularity of situations that lead to preservation of fossils, probably related to a temporal and paleoenvironmental window, as well as the erosive window which gradually exposes the caves, what need to be even better understood in relation to the regional system as a whole. The studied caves still have great paleontological potential, since hundreds of fossils were recorded. If environmental impact studies are developed in the future, it is necessary considering the significant occurrence of fossils. It is recommended controlled excavations to also register fossils in situ, obtaining stratigraphic control and better definition of temporal averaging. Because of the strong rainwater infiltration and runoff onto these caves, it is also highly recommended periodic monitoring of deposits, ideally annual or biennial, so that fossils eventually exposed during storms can be rescued, minimizing the loss of paleontological information. We hope that the current work could guide future detailed dating of events related to the history of these caves, showing which materials should be dated according to the taxonomy, number of individuals or taphonomic groups. Also can to base future research on the stratigraphy of the deposits, ecological and paleobiogeographic relationships over time and evolution of the regional karstic system.

\section{Acknowledgment}

The authors acknowledge to Serviço Geológico do Brasil-CPRM for funding the project and granting scholarship during DEFB and TS stage. Castor Cartelle (Pontifícia Universidade Católica de Minas Gerais) for the access to the collections and support in fossils identification. Rodrigo Machado (Departamento Nacional de Produção Mineral) for the access to Museu de Ciências da Terra collection. Carolina Saldanha Scherer (Universidade Federal do Recôncavo da Bahia), Leonardo Souza Lobo (Museu Nacional - Universidade Federal do Rio de Janeiro), Hermínio de Araújo-Júnior (Universidade do Estado do Rio de Janeiro), Dimila Mothé and Alline Rotti (Universidade Federal do Estado do Rio de Janeiro) for supporting the fossil identification and other contributions. Rafael Henrique Grudka Barroso, Livia Medeiros Cordeiro, Leda Zogbi, Allan Calux and Mr. Nogueira for the support in the field work. Jessika Batista de Souza and Joana Pereira Ribeiro for their support developing the work. Maria Izabel Manes for translating and revising the manuscript. We also thank the anonymous reviewers who greatly contributed to the improvement of the manuscript.

LSA thanks the Conselho Nacional de Desenvolvimento Científico e Tecnológico (CNPq) for the Research Fellowship "Produtividade em Pesquisa" (307555/2016-0) and the Fundação Carlos Chagas Filho de Amparo à Pesquisa do Estado do Rio de Janeiro (FAPERJ) for the Research Fellowship "Jovem Cientista do Nosso Estado".

\section{Appendix A. Supplementary data}

Supplementary data to this article can be found online at https:// doi.org/10.1016/j.jsames.2018.12.004.

\section{References}

Andrade, L.C., Maniesi, V., Adamy, A., 2017. Microestruturas ósseas e a fossilização em vertebrados pleistocênicos da Formação Rio Madeira, Sudoeste Amazônico, Brasil. In: Geologia USP, vol. 17. pp. 125-138.

Araújo, F.A.P., Sesoko, N.F., Rahal, S.C., Teixeira, C.R., Müller, T.R., Machado, M.R.F., 2013. Bone morphology of the hind limbs in two caviomorph rodents. Anat. Histol. Embryol. 42, 114-123.

Araújo-Júnior, H.I., 2016. Classifying vertebrate assemblages preserved in Quaternary tank deposits: implications for vertebrate taphonomy and paleoecology. Palaeogeogr. Palaeoclimatol. Palaeoecol. 445, 147-152.

Araújo-Júnior, H.I., Porpino, K., 2011. Assembleias fossilíferas de mamíferos do Quaternário do Estado do Rio Grande do Norte, Nordeste do Brasil: diversidade e aspectos tafonômicos e paleoecológicos. Pesqui. em Geociencias 38, 67-83.

Araújo-Júnior, H.I., Bissaro-Júnior, M.C., Santos, T.T., Alves, R.S., Bergqvist, L.P., 2012. Tafonomia da megafauna pleistocênica brasileira: fluvial Transport Index (FTI) em análises de representatividade óssea. Rev. Bras. Palaontol. 15, 95-104.

Auler, A.S., Farrant, A.R., 1996. A brief introduction to karst and caves in Brazil. Proc. Univ. Bristol Spelaeol. Soc. 20, 187-200.

Auler, A., Rubbioli, E., Brandi, R., 2001. As Grandes Cavernas Do Brasil. Grupo Bambuí de Pesquisas Espeleológicas, Belo Horizonte 228 pp.

Auler, A.S., Piló, L.B., Saadi, A., 2003. Ambientes cársticos. In: Souza, C.R.G., Suguio, K., Oliveira, A.M.S., Oliveira, P.E. (Eds.), Quaternário Do Brasil. Ribeirão Preto. Holos Editora, pp. 321-342.

Auler, A.S., Piló, L.B., Smart, P.L., Wang, X.F., Hoffmann, D., Richards, D.A., Edwards, R.L., Neves, W.A., Cheng, H., 2006. U-series dating and taphonomy of Quaternary vertebrates from Brazilian caves. Palaeogeogr. Palaeoclimatol. Palaeoecol. 240, 508-522. https://doi.org/10.1016/j.palaeo.2006.03.002.

Auler, A.S., Smart, P.L., Wang, X., Piló, L.B., Edwards, R.L., Cheng, H., 2009. Cyclic sedimentation in Brazilian caves: mechanisms and palaeoenvironmental significance. Geomorphology 106, 142-153.

Bargo, M.S., De Iuliis, G., Vizcaíno, S.F., 2006. Hypsodonty in Pleistocene ground sloths. Acta Palaeontol. Pol. 51, 53-61.

Behrensmeyer, A.K., 1978. Taphonomic and ecologic information from bone weathering. Paleobiology 4, 150-162.

Fossils in the making. In: Behrensmeyer, A.K., Hill, A.P. (Eds.), Vertebrate Taphonomy and Paleoecology. The University of Chicago Press, Chicago 338 pp.

Behrensmeyer, A.K., Damuth, J.D., Dimichele, W.A., Potts, R., Sues, H.D., Wings, S.L, 1992. Terrestrial Ecosystems Trough Time. University of Chicago Press, Chicago $568 \mathrm{pp}$.

Bichuette, M.E., Rizzato, P.P., 2012. A new species of cave catfish from Brazil, Trichomycterus rubbioli sp.n., from Serra do Ramalho karstic área, São Francisco River basin, Bahia State (Siluriformes: trichomycteridae). Zootaxa 3480, 48-66.

Bitencourt, A.L.V., Rodet, J., 2002. Evolução morfológica do canion do Morro Furado no contexto dos calcários carstificados do Grupo Bambuí (Serra do Ramalho, Bahia, Brasil). In: O Carste, vol. 14. pp. 224-237.

Buchmann, F.S.C., Frank, H.T., Ferreira, V.M.S., Cruz, E.A., 2016. Evidência de Vida gregária em paleotocas atribuídas a Mylodontidae (Preguiças-Gigantes). Rev. Bras. Palaontol. 19, 259-270.

Buchmann, R., Guimarães, M.S., Rocha-dos-Santos, B.C.A., Pinheiro, R.S., Rotti, A., Ávilla, L.S., Freitas, J., Araújo-Júnior, H.I., 2017. Mamíferos fósseis do Quaternário da Gruta Tacho de Ouro, Tocantins, Norte do Brasil: diversidade, tafonomia e aspectos paleoicnológicos e paleoambientais. Rev. Bras. Palaontol. 20, 203-218.

Carranza-Castaneda, O., Miller, W.E., 1988. Roedores caviomorfos de la Mesa Central de México, Blancano Temprano (Plioceno Tardío) de la fauna local Rancho Viejo, Estado de Guanajuato, vol. 7. Universidad Nacional Autónoma de México, Instituto de Geologia Revista, pp. 182-199.

Cartelle, C., 1994. Presença de Lama (Artiodactyla, Camelidae) no Pleistoceno final holoceno de Bahia. Acta Geol. Leopoldensia 17, 399-410.

Cartelle, C., 1999. Pleistocene mammals of the Cerrado and caatinga of Brazil. In: Eisenberg, J.F., Redford, K.H., edits (Eds.), Mammals of the Neotropics. The University of Chicago Press, Chicago, pp. 27-46.

Cartelle, C., Abuhid, V.S., 1989. Novos espécimes brasileiros de Smilodon populator Lund, 1842 (Carnivora, Machairodontinae): morfologia e conclusões taxonômicas. In: Congresso Brasileiro de Paleontologia 11, vol. 1. SBP, Curitiba, Brazil, pp. 607-620.

Cartelle, C., Fonseca, J.S., 1983. Contribuiçào ao melhor conhecimento da pequena preguiça terrícola Nothrotherium maquinense (Lund) Lydekker, 1889. Lundiana 2, $127-181$.

Cartelle, C., Bohórquez, G.A., 1984. Pampatherium paulacoutoi, uma nova espécie de tatu gigante da Bahia, Brasil (Edentata, Dasypodidae). Rev. Bras. Zool. 2, 229-254.

Cartelle, C., Lessa, G., 1988. Descrição de um novo gênero e espécie de Macraucheniidae (Mammalia, Litopterna) do Pleistoceno do Brasil. Paula-Coutiana 3, 3-26.

Cartelle, C., De Iuliis, G., 1995. Eremotherium laurillardi: the panamerican late Pleistocene megatheriid sloth. J. Vertebr. Paleontol. 15, 830-841.

Cartelle, C., De Iuliis, G., Pujos, F., 2008. A new species of Megalonychidae (mammalia, Xenarthra) from the quaternary of poço azul (Bahia, Brazil). Comptes Rendus Palevol 7, 335-346.

Cartelle, C., De Iuliis, G., Ferreira, R.L., 2009. Systematic revision of tropical Brazilian scelidotheriine sloths (Xenarthra, mylodontoidea). J. Vertebr. Paleontol. 29, $555-566$.

Cartelle, C., De Iullis, G., Pujos, F., 2014. Eremotherium laurillardi (Lund, 1842) (Xenarthra, Megatheriinae) is the only valid megatheriine sloth species in the Pleistocene of intertropical Brazil: a response to Faure et al., 2014. In: Comptes Rendus Paleovol, vol. 14. pp. 15-23. https://doi.org/10.1016/j.crpv.2014.09.002.

Castro, M.C., 2009. Redescrição de um Dasypodini (Xenarthra, Cingulata) do quaternário 
do estado de São Paulo e considerações sobre o gênero Propraopus Ameghino, 1881 Master Dissertation. Universidade de São Paulo, Brazil 117 pp.

Castro, M.C., Langer, M.C., 2008. New postcranial remains of Smilodon populator Lund, 1842 from southeastern Brazil. Rev. Bras. Palaontol. 11, 199-206.

Castro, M.C., Ribeiro, A.M., Ferigolo, J., Langer, M.C., 2013. Redescription of Dasypus punctatus Lund, 1840 and considerations on the genus Propraopus Ameghino, 1881 (Xenarthra, Cingulata). J. Vertebr. Paleontol. 33, 434-447. https://doi.org/10.1080/ 02724634.2013.729961.

Cisneros, J.C., 2005. New Pleistocene vertebrate fauna from El Salvador. Rev. Bras. Palaontol. 8, 239-255.

Conceição Filho, V.M., Monteiro, M.D., Rangel, P.A., Garrido, I.A.A., 2003. Bacia do São Francisco entre Santa Maria da Vitória e Iuiú, Bahia: geologia e potencialidade econômica. In: Série Arquivos Abertos, vol. 18 CBPM, Salvador 76 pp.

Corona, A., Perea, D., McDonald, H.G., 2013. Catonyx cuvieri (Xenarthra, Mylodontidae, Scelidotheriinae) from the late Pleistocene of Uruguay, with comments regarding the systematics of the subfamily. J. Vertebr. Paleontol. 33, 1214-1225.

Costa Pereira, P.V.L.G., Victer, G.D., Porpino, K.O., Bergqvist, L.P., 2014. Osteoderm histology of Late Pleistocene cingulates from the intertropical region of Brazil. Acta Palaeontol. Pol. 59, 543-552.

Csiki, Z., Grigorescu, D., Codrea, V., Therrien, F., 2010. Taphonomic modes in the Maastrichtian continental deposits of the Haţeg Basin, Romania-palaeoecological and palaeobiological inferences. Palaeogeogr. Palaeoclimatol. Palaeoecol. 293, 375-390.

Dantas, M.A.T., 2012. Contribuição ao conhecimento da megafauna pleistocênica da Região Intertropical Brasileira. PhD Thesis. Universidade Federal de Minas Gerais, Brazil 103pp.

Dantas, M.A.T., Zucon, M.H., 2007. Occurrence of Catonyx cuvieri (Lund, 1839) (tardigrada, Scelidotheriinae) in late pleistocene-holocene of Brazil. Rev. Bras. Palaontol. 10, 129-132.

Dantas, M.A.T., Porpino, K.O., Bauermann, S.G., Prata, A.P.N., Cozzuol, M.A., Kinoshita, A., Barbosa, J.H.O., Baffa, O., 2011. Megafauna do Pleistoceno Superior de Sergipe, Brasil: registros taxonômicos e cronológicos. Rev. Bras. Palaontol. 14, 311-320. https://doi.org/10.4072/rbp.2011.3.10.

Dantas, M.A.T., França, L.M., Cozzuol, M.A., Rincón, A.D., 2013a. About the occurrence of Glyptodon sp. in the Brazilian intertropical region. Quat. Int. 305, 206-208. https://doi.org/10.1016/j.quaint.2011.06.024.

Dantas, M.A.T., Missagia, R., Dutra, R.P., Raugust, L.A.S., Delicio, M.P., Renó, R., 2013b. Identificação taxonômica dos fósseis de mamíferos da caverna Toca Fria e Jatobá, Iuiú, Bahia: inferências paleoecológicas e temporais. In: Rasteiro, M.A., Morato, L., orgs (Eds.), Congresso Brasileiro de Espeleologia 32. SBE, Barreiras, Brazil, pp. 433-438.

Dantas, M.A.T., Cozzuol, M.A., 2016. The Brazilian intertropical fauna from 60 to about 10 ka B.P.: taxonomy, dating, diet, and paleoenvironments. In: Gasparini, G., Rabassa, J., Deschamps, C., Tonni, E. (Eds.), Marine Isotope Stage 3 in Southern South America, 60 KA B.P.-30 KA B.P. Springer Earth System Sciences. Springer, Cham.

Diedrich, C.G., 2007. Upper Pleistocene Panthera leo spelaea (Goldfuss, 1810) skeleton remains from Praha-Podbaba and other lion finds from loess and river terrace sites in Central Bohemia (Czech Republic). Bull. Geosci. 82, 99-117. https://doi.org/10. 3140/bull.geosci.2007.02.99.

Eberth, D.A., Currie, P.J., 2005. Vertebrate taphonomy and taphonomic modes. In: Currie, P.J., Koppelhus, E.B. (Eds.), Dinosaur Provincial Park: a Spectacular Ancient Ecosystem Revealed. Indiana University Press, Bloomington, pp. 453-477.

Evans, H.E., de Lahunta, A., 2013. Miller's Anatomy of the Dog. Elsevier Saunders. $4^{\mathrm{a}} \mathrm{ed}$, pp. 872.

Fariña, R.A., Vizcaíno, S.F., De Iuliis, G., 2013. Megafauna: Giant Beasts of Pleistocene South America. Indiana University Press, Bloomington 436 pp.

Gasparini, G.M., Kerber, L., Oliveira, E.V., 2009. Catagonus stenocephalus (Lund in reinhardt, 1880) in the touro passo formation (late Pleistocene), Rio Grande do sul, Brazil. Taxonomic and paleoenvironmental comments. In: Neues Jahrbuch für Geologie und Paläontologie, vol. 254. pp. 261-273.

Gasparini, G.M., Ferrero, B.S., 2010. The Tayassuidae (mammalia, Artiodactyla) from the quaternary of entre rios province. A paleofaunal review in Argentina. In: Neues Jahrbuch für Geologie und Paläontologie, vol. 256. pp. 151-160.

Gasparini, G.M., Ubilla, M., Tonni, E.P., 2013. The chacoan peccary, Catagonus wagneri (mammalia, Tayassuidae), in the late Pleistocene (northern Uruguay, south America): paleoecological and paleobiogeographic considerations. Hist. Biol.: Int. J. Paleobiol. 25, 679-690.

Gasparini, G.M., Rodriguez, S.G., Soibelzon, L.H., Beilinson, E., Soibelzon, E., Missagia, R.V., 2014. Tayassu pecari (Link, 1795) (Mammalia, Cetartiodactyla): comments on its South American fossil record, taxonomy and paleobiogeography. Hist. Biol.: Int. J. Paleobiol. 26, 1-16.

Gasparini, G.M., Holanda, E.C., Araújo-Júnior, H.I., Ávilla, L.S., 2015. A Quaternary very young juvenile Tapirus Brisson, 1762 (Mammalia, Perissodactyla) from a cave deposit in northern Brazil: taxonomy and taphonomy. Hist. Biol. 28, 803-811.

Ghilardi, A.M., Fernandes, M.A., Bichuette, M.E., 2011. Megafauna from the late pleistocene-holocene deposits of the upper ribeira karst area, southeast Brazil. Quat. Int. 245, 369-378.

Góis, F., Scillato-Yané, G.J., Carlini, A.A., Ubilla, M., 2012. Una nueva especie de Holmesina Simpson (Xenarthra, Cingulata, Pampatheriidae) del Pleistoceno de Rondônia, Sudoeste de la Amazonia, Brasil. Rev. Bras. Palaontol. 15, 211-227.

Guérin, C., Faure, M., Simões, P.R., Hugueney, M., Mourer-Chauviré, C., 2002. Toca da Janela da Barra do Antonião (São Raimundo Nonato), PI - Rica fauna pleistocênica e registro da Pré-historia brasileira. In: Schobbenhaus, C. (Ed.), Sítios Geológicos e Paleontológicos do Brasil, Departamento Nacional de Produção Mineral (DNPM), Serviço Geológico do Brasil (CPRM) e Comissão Brasileira de Sítios Geológicos e
Paleobiológicos (SIGEP), Brasília, pp. 131-137 (Orgs.).

Guérin, C., Faure, M., 2004. Scelidodon piauiense nov. sp., nouveau Mylodontidae Scelidotheriinae (Mammalia, Xenarthra) du Quaternaire de la région du parc national Serra da Capivara (Piauí, Brésil). Comptes Rendus Palevol 3, 35-42.

Guérin, C., Faure, M., 2009. Les Cervidae (Mammalia, Artiodactyla) du Plèistocène supérieur-Holocène ancien de la région du Parc National Serra da Capivara (Piauí, Brésil). Geobios 42, 169-195.

Guérin, C., Faure, M., 2013. Un nouveau Toxodontidae (mammalia, Notoungulata) du Pléistocène supérieur du Nordeste du Brésil. Geodiversitas 35, 155-205. https://doi. org/10.5252/g2013n1a7.

Holanda, E.C., 2007. Os Tapiridae (Mammalia, Perissodactyla) do Pleistoceno superior do estado de Rondônia, Brasil. Master Dissertation. Universidade Federal do Rio Grande do Sul, Brazil 79 pp.

Holanda, E.C., Ferigolo, J., Ribeiro, A.M., 2011. New Tapirus species (mammalia: Perissodactyla: Tapiridae) from the upper Pleistocene of amazonia, Brazil. J. Mammal. 92, 111-120. https://doi.org/10.1644/10-MAMM-A-144.1.

Hubbe, A., Hubbe, M., Neves, W.A., 2009. New late-pleistocene dates for the extinct megafauna of Lagoa Santa, Brazil. Curr. Res. Pleistocene 26, 154-156.

Hubbe, A., Haddad-Martim, P.M., Hubbe, M., Mayer, E.L., Strauss, A., Auler, A.S., Piló, L.B., Neves, W.A., 2011. Identification and importance of critical depositional gaps in pitfall cave environments: the fossiliferous deposit of Cuvieri Cave, eastern Brazil. Palaeogeogr. Palaeoclimatol. Palaeoecol. 312, 66-78. https://doi.org/10.1016/j. palaeo.2011.09.010.

Hubbe, A., Auler, A.S., 2012. A large cervidae Holocene accumulation in Eastern Brazil. An extreme example of taphonomical control in a cave environment. Int. J. Speleol. 41, 299-307.

ICVGAN - International Comittee on Veterinary Gross Anatomical Nomenclature, 2012. Nomina Anatomica Veterinaria. In: Published by the Editorial Comittee, Hannover, Germany, Columbia, New York, Gent, Belgium, and Sapporo, Japan, 166pp.

Kerber, L., Ribeiro, A.M., 2011. Capybaras (Rodentia: hystricognathi: Hydrochoeridae) from the late Pleistocene of southern Brazil. Neues Jahrbuch Geol. Palaontol. Abhand. 261, 1-18.

Kerber, L., 2017. Imigrantes em um continente perdido: O registro fossilífero de roedores Caviomorpha (Mammalia: Rodentia: Ctenohystrica) do Cenozoico do Brasil. In: Terræ Didatica, vol. 13. pp. 182-211.

Klaus, G., Klaus-Hügi, C., Schmid, B., 1998. Geophagy by large mammals at natural licks in the rain forest of the Dzanga National Park, Central African Republic. J. Trop. Ecol. 14, 829-839.

Le, M., Raxworthy, C.J., McCord, W.P., Mertz, L., 2006. A molecular phylogeny of tortoises (Testudines: Testudinidae) based on mitochondrial and nuclear genes. Mol. Phylogenet. Evol. 450, 517-531.

Leiggi, P., May, P., 1994. Vertebrate Paleontological Techniques, vol. 1 Cambridge University Press, New York 380 pp.

Lessa, G.M., 1992. Estudo descritivo de Xenorhinotherium bahiense Cartelle and Lessa, 1988 e comparação com outras espécies de Macraucheniidae (Litopterna, Mammalia). Master Dissertation. Universidade Federal do Rio de Janeiro, Brazil 263 pp.

Lôbo, D., Silva, E.J., Carvalho, J.L.G., Santos, L.C.M., Santana, M.O., Leão, T.C.C., Zucon, M.H., Valerio, M.E.G., 2007. Ocorrência de Geochelone (Reptilia-Testudinidae) no Abismo de Simão Dias, Sergipe, Brasil. In: Revista Direto do Centro da Terra, vol. 1. pp. 5-8.

Lopes, R.P., Pereira, J.C., 2010. Fossils of Scelidotheriinae Ameghino, 1904 (Xenarthra, Pilosa) in the Pleistocene deposits of Rio Grande do sul, Brazil. Gaea - J. Geosci. 6, 44-52.

Luna, C.A., Cerda, I.A., Zurita, A.E., Gonzalez, R., Prieto, M.C., Mothé, D., Avilla, L.S., 2018. Distinguishing Quaternary glyptodontine cingulates in South America: how informative are juvenile specimens? Acta Palaeontol. Pol. 63, 159-170.

Lyman, R.L., 1994. Vertebrate Taphonomy. Cambridge University Press, Cambridge 524 pp.

Maciel, L., Ribeiro, A.M., Sedor, F., 1996. Considerações sobre quelônios fósseis do Quaternário do Rio Grande do Sul, Brasil. Ameghiniana 33, 467.

Maldonado, V., Monteiro, L.G.P., Rotti, A., Pereira, C., Araújo-Júnior, H.I., Avilla, L.S., 2016. Taphonomic aspects of deer (mammalia, Cetartiodactyla, cervidae) remains from a quaternary cave deposit in northern Brazil. J. Sediment. Environ. 1, 234-248.

Manzano, A., Noriega, J., Joyce, W., 2009. The tropical tortoise Chelonoidis denticulate (Testudines: Testudinidae) from the late Pleistocene of Argentina and its paleoclimatological implications. J. Paleontol. 83, 975-980.

Martin, R.E., 1999. Taphonomy: a Process Approach. Cambridge University Press, Cambridge 508 pp.

Meachen-Samuels, J.A., Van Valkenburgh, B., 2010. Radiographs reveal exceptional forelimb strength in the sabertooth cat, Smilodon fatalis. PLoS One 5, e11412. https:// doi.org/10.1371/journal.pone.0011412.

Mendonça, R., 2012. Diversidade de toxodontes pleistocênicos (Notoungulata, Toxodontidae): uma nova visão. PhD Thesis. Universidade de São Paulo, Brazil $166 \mathrm{pp}$.

Mohamed, R., 2018. A descriptive morphometric approach of the skull and mandible of the common opossum (Didelphis marsupialis Linnaeus, 1758) in the caribbean and its clinical application during regional anaesthesia. Veterin. Sci. 5, 1-10. https://doi. org $/ 10.3390 /$ vetsci5010029.

Mones, A., Ojasti, J., 1986. Hydrochoerus hydrochaeris. Mamm. Species 264, 1-7.

Mones, A., 1991. Monografía de la Familia Hydrochoeridae (mammalia, Rodentia). Sistemática-Paleontología-Bibliografía. Cour. Forschungsinst. Senckenberg 134, $1-235$.

Mothé, D., Avilla, L.S., Cozzuol, M., Winck, G.R., 2012. Taxonomic revision of the quaternary gomphotheres (mammalia: Proboscidea: Gomphoteriidae) from the south American lowlands. Quat. Int. 276/277, 2-7. 
Mothé, D., Avilla, L.S., Asevedo, L., Borges-Silva, L., Rosas, M., Labarca-Encina, R., Souberlich, R., Soibelzon, E., Roman-Carrion, J.L., Ríos, S.D., Rincon, A.R., Oliveira, G.C., Lopes, R.P., 2017. Sixty years after 'The mastodonts of Brazil': the state of the art of South American proboscideans (Proboscidea, Gomphotheriidae). Quat. Int. 443, 52-64.

Neto, F.M., Ribeiro, L.C.B., 2016. Paleontologia. In: Sánchez, L.E., Lobo, H.A.S., Orgs (Eds.), Guia de Boas Práticas Ambientais na Mineração de Calcário em Áreas Cársticas. Sociedade Brasileira de Espeleologia, Campinas, pp. 164-184.

Nova, P.V., Avilla, L.S., Oliveira, E.V., 2015. Didelphidae marsupials (mammalia, Didelphimorphia) from the late Pleistocene deposit of the gruta dos moura cave, northern Brazil. An Acad. Bras Ciências 87, 193-208. https://doi.org/10.1590/00013765201520140229.

Oliveira, E.V., Kerber, L., 2009. Paleontologia e aspectos geológicos das sucessões do final do Neógeno no sudoeste do Rio Grande do Sul, Brasil. In: Gaea, vol. 5. pp. 21-34. https://doi.org/10.4013/gaea.2009.51.03.

Oliveira, E.V., Porpino, K.O., Barreto, A.F., 2010. On the presence of Glyptotherium in the late Pleistocene of northeastern Brazil, and the status of "Glyptodon" and "chlamydotherium", paleobiogeographic implications. Neues Jahrbuch Geol. Palaontol. Abhand. 258, 353-363.

Oliveira, E.V., Porpino, K.O., Silva, F.M., 2013. New material of Pachyarmatherium from the late Pleistocene of northeastern Brazil: insights into its morphology and systematics. Paläontol. Z. 87, 505-513.

Oliveira, P.V., Ribeiro, A.M., Oliveira, E.V., Viana, M.S.S., 2014. The Dasypodidae (mammalia, Xenarthra) from the urso fóssil cave (quaternary), parque nacional de Ubajara, state of Ceará, Brazil: paleoecological and taxonomic aspects. An Acad. Bras Ciências 86, 147-158. https://doi.org/10.1590/0001-3765201420120029.

Palmer, A.N., 1991. Origin and morphology of limestones caves. Geol. Soc. Am. Bull. 103, $1-21$.

Palmer, A.N., 2007. Cave Geology. Cave Books, Dayton, pp. 454.

Paula-Couto, C., 1959. Uma pequena preguiça terrícola de São Paulo. An Acad. Bras Ciências 31, 91-119.

Paula-Couto, C., 1973. Edentados fósseis de São Paulo. An Acad. Bras Ciências 45, 261-275.

Paula-Couto, C., 1979. Tratado de Paleomastozoologia. Academia Brasileira de Ciências, Rio de Janeiro 590 pp.

Piló, L.B., 1988. Morfologia cárstica e materiais constituintes: dinâmica e evolução da depressão poligonal Macacos-Baú - Carste de Lagoa Santa, MG. PhD Thesis. Universidade de São Paulo, Brazil 275 pp.

Piló, L.B., Neves, W.A., 2003. Novas datações 14C (AMS) confirmam a tese da coexistência do homem com a megamastofauna pleistocênica na região cárstica de Lagoa Santa, MG. In: Congresso Brasileiro de Espeleologia, vol. 27. SBE, Campinas, Brazil, pp. 100-104.

Porpino, K.O., Fernicola, J.C., Bergqvist, L.P., 2009. A new Cingulate (Mammalia: Xenarthra) Pachyarmatherium brasiliense sp. nov. from the late Pleistocene of northeastern Brazil. J. Vertebr. Paleontol. 29, 881-893.

Porpino, K.O., Fernicola, J.C., Bergqvist, L.P., 2010. Revisiting the intertropical Brazilian species Hoplophorus euphractus (Cingulata, Glyptodontoidea) and the phylogenetic affinities of Hoplophorus. J. Vertebr. Paleontol. 30, 911-927.

Prevosti, F.J., Vizcaíno, S.F., 2006. Paleoecology of the large carnivore guild from the late Pleistocene of Argentina. Acta Palaeontol. Pol. 51, 407-422.

Reis, N.R., Peracchi, A.L., Pedro, W.A., Lima, I.P., 2006. Mamíferos Do Brasil. Londrina, Paraná. 237 pp.

Rodrigues, S., Avilla, L.S., Soibelzon, L.H., Bernardes, C., 2014. Late Pleistocene carnivores (Carnivora: mammalia) from a cave sedimentary deposit in northern Brazil. An Acad. Bras Ciências 86, 1641-1655.

Romer, A.S., Parsons, T.S., 1985. Anatomia Comparada Dos Vertebrados. Atheneu Editora São Paulo LTDA, São Paulo 559 pp.

Rotti, A., Mothé, D., Avilla, L.S., Semprebon, G.M., 2018. Diet reconstruction for an extinct deer (cervidae: Cetartiodactyla) from the quaternary of south America. Palaeogeogr. Palaeoclimatol. Palaeoecol. 497, 244-252.

Santos, M.F.C.F., Bergqvist, L.P., Lima-Filho, F.P., Pereira, M.M.V., 2002. Feições tafonômicas observadas em fósseis pleistocênicos do Rio Grande do Norte. In: Revista de Geologia, vol. 15. pp. 31-41.

Sausse, O., 2013. Exploração da parte oeste do Maciço do Coração. In: O Carste, vol. 25. pp. $50-52$.

Scherer, C.S., 2005. Estudo Dos Camelidae (Mammalia, Artiodactyla) Do Quaternário Do Estado Do Rio Grande Do Sul, Brasil. Master Dissertation. Universidade Federal do Rio Grande do Sul, Brazil 176 pp.

Scherer, C.S., 2009. Os Camelidae Lamini (Mammalia, Artiodactyla) do Pleistoceno da América do Sul: aspectos taxonômicos e filogenéticos. $\mathrm{PhD}$ Thesis. Universidade Federal do Rio Grande do Sul, Brazil 460 pp.

Scherer, C.S., Pitana, V.G., Ribeiro, A.M., 2009. Protherotheriidae and Macraucheniidae (Litopterna, mammalia) from the Pleistocene of Rio Grande do sul state, Brazil. Rev. Bras. Palaontol. 12, 231-246.

Scherer, C.S., Pales, L.F.M., Mariane Rosa, M., Silva, S.A., 2017. Chronological, taphonomical, and paleoenvironmental aspects of a Late Pleistocene mammalian fauna from Guanambi, Bahia, Brazil. J. S. Am. Earth Sci. 79, 95-110. https://doi.org/10. 1016/j.jsames.2017.07.016.

Scheffler, S.M., Martins, G.R., Kashimoto, E.M., Oliveira, A.M., 2010. Revisão sobre a paleontologia no estado do Mato Grosso do Sul: fósseis e afloramentos descritos. Braz. Geogr. J. 1, 65-99.

Scillato-Yané, G.J., Carlini, A.A., Tonni, E.P., Noriega, J.I., 2005. Paleobiogeography of the late Pleistocene pampatheres of south America. J. S. Am. Earth Sci. 20, 131-138.

Sedor, F.A., Born, P.A., Santos, F.M.S., 2004. Fósseis pleistocênicos de Scelidodon (Mylodontidae) e Tapirus (Tapiridae) em cavernas paranaenses (PR, sul do Brasil). Acta Biol. Parana. 33, 121-128.

Shipman, P., 1981. Life History of a Fossil: an Introduction to Taphonomy and Paleoecology. Harvard University Press, Cambridge 222 pp.

Simms, M.J., 1994. Emplacement and preservation of vertebrates in caves and fissures. Zool. J. Linn. Soc. 112, 261-283.

Siqueira, R.C., Rahal, S.C., Inamassu, L.R., Mamprim, M.J., Felix, M., Castilho, M.S., Mesquita, L.R., Ribeiro, V.L., Teixeira, C.R., Rassy, F.B., 2017. Osteology and radiology of the Maned Wolf (Chrysocyon brachyurus) pelvic limb. Anat. Histol. Embryol. 46, 572-581. https://doi.org/10.1111/ahe.12314.

Smith, J.B., Dodson, P., 2003. A proposal for a standard terminology of anatomical notation and orientation in fossil vertebrate dentitions. J. Vertebr. Paleontol. 23, 1-12.

Soibelzon, L.H., Tartarini, V.B., 2009. Estimación de la masa corporal de las especies de osos fósiles y actuales (Ursidae, Tremarctinae) de América del Sur. In: Revista Museo Argentino de Ciencias Naturales "Bernardino Rivadavia", vol. 11. pp. 243-254.

Soibelzon, E., Avilla, L.S., Castro, M., 2015. The cingulates (Mammalia: Xenarthra) from the late Quaternary of northern Brazil: fossil records, paleoclimates and displacements in America. Quat. Int. 377, 118-125.

Stríkis, N.M., Cruz, F.W., Barreto, E.A.S., Naughton, F., Vuille, M., Cheng, H., Voelker, A.H.L., Zhang, H., Karmann, I., Edwards, R.L., Auler, A.S., Santos, R.V., Sales, H.R., 2018. South American monsoon response to iceberg discharge in the North Atlantic. Proc. Natl. Acad. Sci. Unit. States Am. 115, 3788-3793.

Valli, A.M.F., 2018. Late Pleistocene Deer in the Region of the National Park "Serra da Capivara" (Piauí, Brazil). In: Quaternary, vol. 1https://doi.org/10.3390/ quat1010004. $18 \mathrm{pp}$

Vasconcelos, A.G., Meyer, K.E.B., Campello, M.S., 2015. Mamíferos quaternários da cavidade ES-08, Município de Prudente de Morais, Minas Gerais: análises tafonômica e taxonômica. Rev. Bras. Palaontol. 18, 171-190. https://doi.org/10.4072/rbp.2015. 1.12 .

Vasconcelos, A.G., Kraemer, B.M., Meyer, K.E.B., 2018. Tafonomia em cavernas brasileiras: histórico e método de coleta de fósseis preservados em solo carbonatado. In: Terrae didática, Campinas, vol. 14. pp. 49-68.

Winge, H., 1915. Jordfundne og nulevende Gumlere (Edentata) fra Lagoa Santa, Minas Gerais, Brasilien. E. Museo Lundii. In: Copenhague, vol. 3321 pp.

Wood, J.M., Thomas, R.G., Visser, J., 1988. Fluvial process and vertebrates taphonomy: the upper cretaceous Judith River formation, south-central dinosaur provincial park, Alberta, Canada. Palaeogeogr. Palaeoclimatol. Palaeoecol. 66, 127-143.

Zalán, P.V., Silva, P.C.R., 2007. Bacia do São Francisco. Bol. Geociencias Petrobras 15, 561-571.

Zurita, A.E., Miño-Boilini, A.R., Francia, A., Arenas-Mosquera, J.E., 2012. The Pleistocene Glyptodontidae Gray, 1869 (Xenarthra: Cingulata) of Colombia and some considerations about the south American glyptodontinae. Rev. Bras. Palaontol. 15, 273-280. https://doi.org/10.4072/rbp.2012.3.04. 